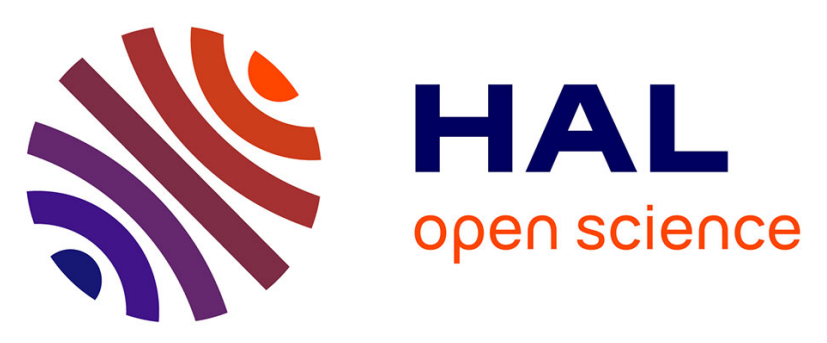

\title{
Paleogene evolution and demise of the proto-Paratethys Sea in Central Asia (Tarim and Tajik basins): role of intensified tectonic activity at ca. $41 \mathrm{Ma}$
}

Mustafa Yücel Kaya, Guillaume Dupont-Nivet, Jean-Noël Proust, Pierrick Roperch, Laurie Bougeois, Et Al.

\section{To cite this version:}

Mustafa Yücel Kaya, Guillaume Dupont-Nivet, Jean-Noël Proust, Pierrick Roperch, Laurie Bougeois, et al.. Paleogene evolution and demise of the proto-Paratethys Sea in Central Asia (Tarim and Tajik basins): role of intensified tectonic activity at ca. 41 Ma. Basin Research, 2019, 31 (3), pp.461-486. 10.1111/bre.12330 . insu-02025954

\section{HAL Id: insu-02025954 https://hal-insu.archives-ouvertes.fr/insu-02025954}

Submitted on 14 Nov 2020

HAL is a multi-disciplinary open access archive for the deposit and dissemination of scientific research documents, whether they are published or not. The documents may come from teaching and research institutions in France or abroad, or from public or private research centers.
L'archive ouverte pluridisciplinaire HAL, est destinée au dépôt et à la diffusion de documents scientifiques de niveau recherche, publiés ou non, émanant des établissements d'enseignement et de recherche français ou étrangers, des laboratoires publics ou privés. 


\title{
Paleogene evolution and demise of the proto-Paratethys Sea in Central Asia (Tarim and Tajik basins): Role of intensified tectonic activity at ca. 41 Ma
}

\author{
Mustafa Y. Kaya ${ }^{1}$ (D) | Guillaume Dupont-Nivet ${ }^{1,2,3}$ | Jean-Noël Proust ${ }^{2}$ | \\ Pierrick Roperch $^{2}$ ｜ Laurie Bougeois ${ }^{4}$ | Niels Meijer ${ }^{1}$ | Joost Frieling $^{5}$ | \\ Chiara Fioroni $^{6}$ | Sevinç Özkan Altıner ${ }^{7}$ | Ezgi Vardar ${ }^{7}$ | Natasha Barbolini ${ }^{8}$ | \\ Marius Stoica $^{9}$ | Jovid Aminov ${ }^{1,10}$ | Mehmut Mamtimin ${ }^{3}$ ～Guo Zhaojie ${ }^{3}$ \\ ${ }^{1}$ Institut für Erd- und Umweltwissenschaften, Universität Potsdam, Potsdam, Germany \\ ${ }^{2}$ CNRS, UMR6118 (Geosciences), Univ Rennes, Rennes, France \\ ${ }^{3}$ Ministry of Education, Key Laboratory of Orogenic Belts and Crustal Evolution, Beijing, China \\ ${ }^{4}$ Ministère de l'Éducation Nationale, Rectorat de l'Académie de Montpellier, Montpellier, France \\ ${ }^{5}$ Department of Earth Sciences, Faculty of Geosciences, Marine Palynology and Paleoceanography, Utrecht University, Utrecht, The Netherlands \\ ${ }^{6}$ Dipartimento di Scienze Chimiche e Geologiche, Università degli Studi di Modena e Reggio Emilia, Modena, Italy \\ ${ }^{7}$ Department of Geological Engineering, Middle East Technical University, Ankara, Turkey \\ ${ }^{8}$ Department of Ecosystem \& Landscape Dynamics, Institute for Biodiversity \& Ecosystem Dynamics (IBED), University of Amsterdam, Amsterdam, The \\ Netherlands \\ ${ }^{9}$ Department of Geology, Faculty of Geology and Geophysics, University of Bucharest, Bucharest, Romania \\ ${ }^{10}$ Institute of Geology, Earthquake Engineering and Seismology, Dushanbe, Tajikistan
}

\section{Correspondence}

Mustafa Y. Kaya, Institut für Erd- und

Umweltwissenschaften, Universität

Potsdam, Potsdam, Germany.

Email: mustafayk@gmail.com

Funding information

ERC, Grant/Award Number: MAGIC 649081

\begin{abstract}
The proto-Paratethys Sea covered a vast area extending from the Mediterranean Tethys to the Tarim Basin in western China during Cretaceous and early Paleogene. Climate modelling and proxy studies suggest that Asian aridification has been governed by westerly moisture modulated by fluctuations of the proto-Paratethys Sea. Transgressive and regressive episodes of the proto-Paratethys Sea have been previously recognized but their timing, extent and depositional environments remain poorly constrained. This hampers understanding of their driving mechanisms (tectonic and/or eustatic) and their contribution to Asian aridification. Here, we present a new chronostratigraphic framework based on biostratigraphy and magnetostratigraphy as well as a detailed palaeoenvironmental analysis for the Paleogene protoParatethys Sea incursions in the Tajik and Tarim basins. This enables us to identify the major drivers of marine fluctuatiowns and their potential consequences on Asian aridification. A major regional restriction event, marked by the exceptionally thick $(\leq 400 \mathrm{~m})$ shelf evaporites is assigned a Danian-Selandian age (ca. 63-59 Ma) in the Aertashi Formation. This is followed by the largest recorded proto-Paratethys Sea
\end{abstract}


incursion with a transgression estimated as early Thanetian (ca. 59-57 Ma) and a regression within the Ypresian (ca. 53-52 Ma), both within the Qimugen Formation. The transgression of the next incursion in the Kalatar and Wulagen formations is now constrained as early Lutetian (ca. 47-46 Ma), whereas its regression in the Bashibulake Formation is constrained as late Lutetian (ca. $41 \mathrm{Ma}$ ) and is associated with a drastic increase in both tectonic subsidence and basin infilling. The age of the final and least pronounced sea incursion restricted to the westernmost margin of the Tarim Basin is assigned as Bartonian-Priabonian (ca. 39.7-36.7 Ma). We interpret the long-term westward retreat of the proto-Paratethys Sea starting at ca. $41 \mathrm{Ma}$ to be associated with far-field tectonic effects of the Indo-Asia collision and Pamir/Tibetan plateau uplift. Short-term eustatic sea level transgressions are superimposed on this longterm regression and seem coeval with the transgression events in the other northern Peri-Tethyan sedimentary provinces for the 1 st and 2 nd sea incursions. However, the 3 rd sea incursion is interpreted as related to tectonism. The transgressive and regressive intervals of the proto-Paratethys Sea correlate well with the reported humid and arid phases, respectively in the Qaidam and Xining basins, thus demonstrating the role of the proto-Paratethys Sea as an important moisture source for the Asian interior and its regression as a contributor to Asian aridification.

\section{1 | INTRODUCTION}

The proto-Paratethys Sea, extended across Eurasia from the Mediterranean Tethys to the Tarim Basin in western China during Cretaceous to Paleogene times. The proto-Paratethys Sea fluctuations as well as its long-term incursion and retreat out of Central Asia are well expressed at its eastern end in the Tarim Basin where three Paleogene sea incursions were previously recognized (Burtman, 2000; Lan \& Wei, 1995; Mao \& Norris, 1988; Tang et al., 1989), but their driving mechanisms remain unresolved. Different controlling factors were suggested: (a) tectonism and associated basin overfilling related to the India-Asia collision (Burtman, 2000; Burtman \& Molnar, 1993), (b) global sea level fluctuations (Dupont-Nivet et al., 2007; Sobel \& Dumitru, 1997) and (c) the combined effects of tectonism and global sea level (Bosboom et al., 2017, 2014a, 2011; Zhang, Hu, Han, Li, \& Garzanti, 2018).

Previous efforts have contributed to constrain the timing, extent and depositional environments of the sea fluctuations (Sun \& Jiang, 2013; Sun et al., 2016; Wan et al., 2014; Zhang et al., 2018). In particular, Bosboom et al. (2017, 2014a, 2014b, 2011) dated the 2nd and 3rd Paleogene regression events. Despite this, the lack of data for the age and palaeogeography of all individual transgression and regression events still hampers understanding the role of tectonics and eustasy on the sea incursions and their palaeoclimatic consequences on regional aridification.

Central Asia shifted from a subtropical climate to the onset of inland deserts during the Cenozoic (e.g. Guo et al., 2008),

\section{Highlights}

- New regional stratigraphic framework provides more solid age constraints for the early Paleogene sea incursions in the SW Tarim and Tajik basins.

- The long-term westward retreat of the protoParatethys Sea starting at ca. $41 \mathrm{Ma}$ is interpreted as being caused by increasing far-field tectonic effects (increased clastics and basin infilling) associated with the Pamir/Tibetan tectonic activity.

- The transgressive/regressive intervals of the proto-Paratethys Sea in the SW Tarim Basin coincide with the less arid/more arid phases in the Qaidam and Xining basins, establishing the protoParatethys as a major important moisture source for the Asian interior and demonstrating its importance as a contributor to Asian aridification.

however the mechanisms driving this aridification remain elusive. The growth of the Himalaya and Tibetan Plateau in response to the India-Asia collision is one of the proposed mechanisms by forming orographic barriers and creating planetary waves that promote aridity (Kutzbach et al., 1993; Li et al., inpress; Manabe $\&$ Broccoli, 1990). Alternatively, it has been suggested that global cooling during the Cenozoic is driving the aridification by weakening the hydrological cycle (Dupont-Nivet et al., 2007; Li et al., in 
press; Lu et al., 2010). A third view suggests that the westward retreat of the proto-Paratethys Sea was the controlling factor for both the aridification by removing a moisture source, and the intensification of the Asian monsoons by increasing the land-sea contrast (Ramstein et al., 1997; Zhang et al., 2007). However, recent proxy data and climate models show that the sea was too shallow to affect the thermal contrast generating monsoons (Bougeois, 2014; Bougeois et al., 2018; Licht et al., 2016, 2014; Roe et al., 2016; Zhang et al., 2012). Recent indications from proxy and model data rather show that Asian aridification since the early Eocene is linked to a decrease in the westerly moisture flux (Caves et al., 2015) and that the proto-Paratethys Sea provided moisture via the westerlies which precipitated in Central Asia during wintertime (Bougeois, 2014; Bougeois et al., 2018). However, to what extent this westerly moisture is affected by the fluctuating sea incursions and the long-term sea retreat remains mostly unknown and its influence in eastern Asia remains to be explored.

Central Asian moisture records based on pollen, geochemistry and sedimentological data can be found in the terrestrial (fluvio-lacustrine) deposits in the Xining (Abels et al., 2011; Bosboom et al., 2014a; Meijer et al., 2018) and Qaidam (Bao et al., 2017; Song et al., 2013; Ye et al., 2016) basins, both located further east along the northeastern margin of the Tibetan Plateau. Comparing these records with the proto-Paratethys transgressions and regressions could elucidate the marine influence on atmospheric moisture and aridification of the Asian interior. However, this requires constraining the age and extent of the sea level fluctuations.

To better understand the cause and consequences of the proto-Paratethys Sea fluctuations, this study aims to: (a) document the depositional environments during the Paleogene sea incursions and their evolution; (b) provide an improved regional stratigraphic framework, using new biostratigraphic and magnetostratigraphic constraints for the Paleogene transgressive-regressive phases; and (c) discuss their driving mechanisms (tectonic and/or eustatic) and consequences on regional aridification by examining and comparing to regional records of the sea extent, tectonic settings as well as climate records.

\section{2 | GEOLOGIC SETTING}

\section{1 $\quad$ Tectonic setting}

The Tarim and Tajik basins are part of blocks (or terranes) separated by Palaeozoic and Mesozoic fold belts formed by the successive accretion of Gondwanan continental blocks to Laurasia between the Late Triassic and Eocene (Hendrix et al., 1992; Şengör et al., 1988; Li, 1990; Yin \& Harrison, 2000). Cenozoic northward movement and Eocene accretion of the last continental block (India) to Laurasia created most of the present-day topographies bounding the Tarim and Tajik basins (Figure 1).

To the north of the Tajik and Tarim basins, the evolution of the Tian Shan goes back to the Late Palaeozoic, initiating during the Carboniferous in an ocean subduction-continental accretion tectonic context (Jolivet et al., 2013; Şengör et al., 1993). Its Cenozoic history is still debated with possible early Paleogene tectonic events (e.g. Jolivet et al., 2013) related to propagating deformation from the India-Asia collision. More consensual is the onset of major exhumation well constrained around the Oligocene-Miocene boundary (Sobel et al., 2006; van Hinsbergen et al., 2012; Yang et al., 2015). Before the early Miocene exhumation, the southwestern Tian Shan foreland remained mostly inactive through the Oligocene, as evidenced by limited exhumation, subsidence and accumulation (Heermance et al., 2007; Sobel et al., 2006; Yang et al., 2015). Since ca. $25 \mathrm{Ma}$, the Tian Shan grew through several tectonic pulses (e.g. Qiao et al., 2017; Sun et al., 2009; Yin et al., 1998).

To the south of the Tajik and Tarim basins, early evolution of the Kunlun arc and Karakul-Mazar complex (Kunlun terrane) is associated with closure of the Palaeo-Tethys since at least $200 \mathrm{Ma}$, with exhumation during the Cretaceous, Paleogene and Miocene (e.g. Amidon \& Hynek, 2010; Blayney et al., 2016; Cao et al., 2015). Middle-late Eocene thrusting and exhumation in the West Kunlun Shan and North Pamir, as well as PamirTibetan uplift, magmatism and metamorphism further south in the Qiangtang and Central/South Pamir terranes have been proposed to relate to far-field propagation of deformation from the India-Asia collision (Bershaw et al., 2012; Cowgill, 2010; Chapman et al., 2018; Rutte et al., 2017; Yin et al., 2002 and references therein). Marked thrusting and exhumation of the West Kunlun Shan has been proposed sometime between the late Oligocene and early Miocene (20-26 Ma) propagating north into the Pamir uplifting mainly ca. $15 \mathrm{Ma}$ (e.g. Blayney et al., 2016 and references therein). The onset of the Pamir indentation and uplift separating the Tarim and the Tajik basins has been constrained at ca. 25-20 Ma and continued to propagate north from 15 Ma up to the Pliocene (Blayney et al., 2016; Burtman \& Molnar, 1993; Cowgill, 2010; Sobel \& Dumitru, 1997).

\section{2 | Stratigraphic setting}

The Precambrian (pre-Neoproterozoic) crystalline basement of the Tarim Basin is covered by Phanerozoic strata consisting of Palaeozoic carbonates, marine and nonmarine fine clastics and Mesozoic-Cenozoic red clastics, evaporites and limestones (Li, 1990; Zhang et al., 2013). Paleogene deposits in the western Tarim Basin are represented by the Kashi Group, which is composed of the Aertashi, Qimugen, Kalatar, Wulagen and Bashibulake formations.

From the late Cretaceous and to the late Eocene, the Tarim Basin witnessed several transgressions and regressions, resulting in the deepening/shallowing of the epicontinental protoParatethys Sea and concomitant transitions from marine to continental depositional environments or vice versa (Bosboom et al., 2017, 2014a, 2011; Burtman, 2000; Guo et al., 2015; Xi et al., 2016; Zhang et al., 2018). The easternmost portion 


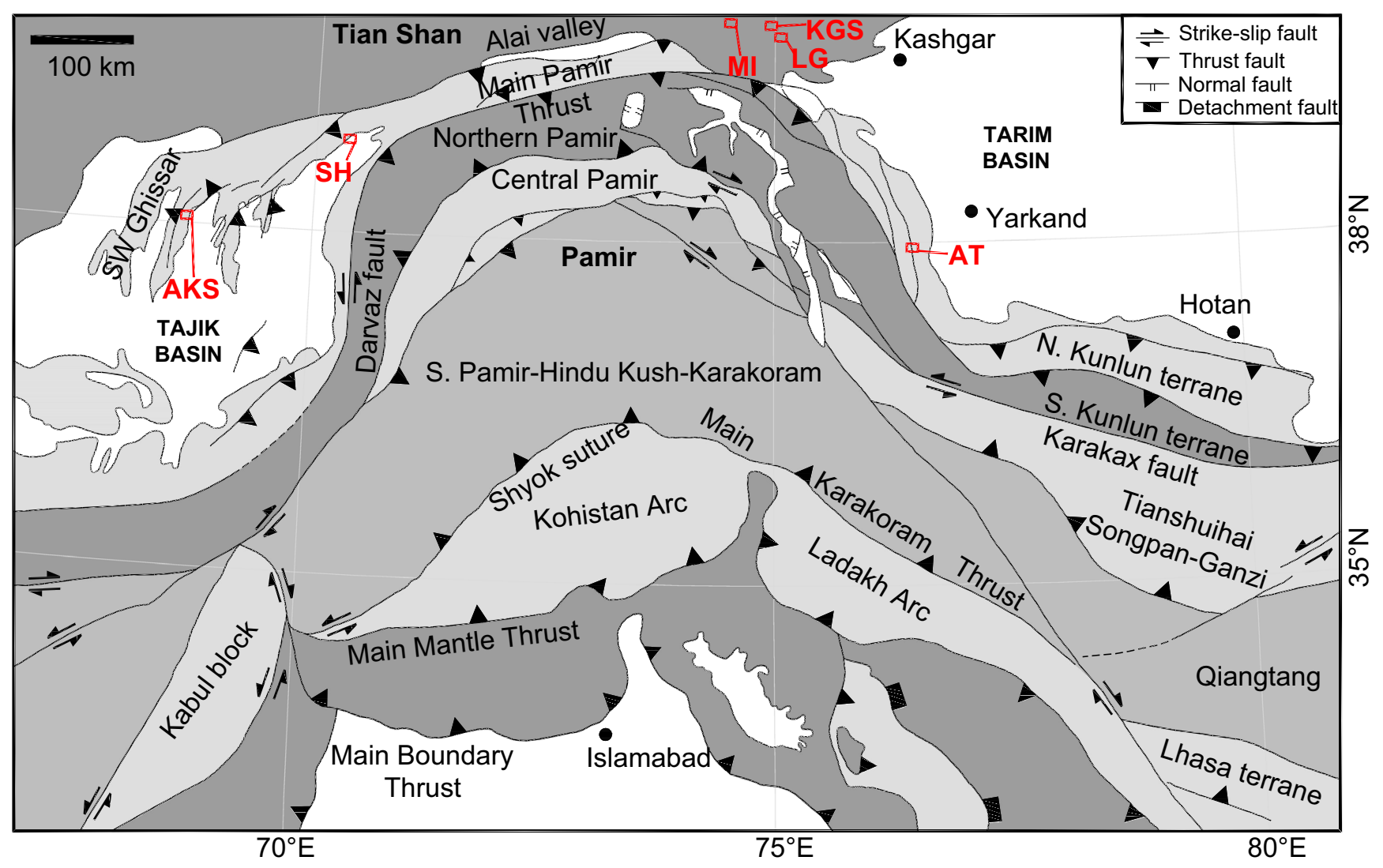

F I G U RE 1 Locations of the studied sections in Tarim (KGS: Kangsu, LG: Laghman, MI: Mine, AT: Aertashi) and Tajik (AKS: Aksu, SH: Shuldara) basins on a schematic map of major tectonic domains within the Pamir and western Tibet (modified from Cowgill, 2010)

of the proto-Paratethys Sea in the western Tarim Basin was connected with the Tajik Basin, as evidenced by the similar stratigraphic and sedimentary successions in both basins (Bosboom et al., 2017; Burtman, 2000). Similarities of the fossil assemblages with other basins in Central Asia and Europe indicate that this portion of the Proto-Paratethys in the western Tarim Basin was also a part of the Tethyan Realm (Bosboom et al., 2011; Mao \& Norris, 1988). It is widely accepted that the first Cretaceous marine incursion in the southwestern Tarim Basin is represented by a Cenomanian transgression, followed by other transgressions during Coniacian and Campanian (Burtman, 2000; Burtman \& Molnar, 1993; Guo et al., 2015). Thick and extensive early Palaeocene evaporites of the Aertashi Formation provide evidence for a regional restriction event. The first Paleogene transgression is characterized by the shelly marls of the lower member of the Qimugen Formation, which represents the maximum extent and deepest environments of the Proto-Paratethys Sea in the Tarim Basin. The succeeding regression is recorded in the gypsiferous mud deposits of the upper member of the Qimugen Formation. The marine Kalatar Formation limestones and silty shales of the Wulagen Formation are associated with the penultimate transgression, whereas the silty shales of the Bashibulake Formation were deposited during the last smaller marine transgression (Bosboom et al., 2011 and references therein). Our study focuses mainly on the transgressions represented by the lower member of the Qimugen, Kalatar and Wulagen formations and the regression recorded in the upper member of the Qimugen Formation.

\section{MATERIAL AND METHODS}

We analysed three detailed sedimentological sections (Aertashi, Mine and Kangsu) and one lithostratigraphic section (Laghman) from the SW and NW Tarim Basin (Figure 1). Two lithostratigraphic sections (Aksu and Shuldara) from the Tajik Basin, including the records of the last two marine incursions recognized in the Tarim Basin (Bosboom et al., 2017), were re-examined and new biostratigraphic results were obtained from nannofossils and dinoflagellate cysts (dinocysts). Previously published palyno-assemblages from the Tarim Basin together with new palynogical samples provide a reconstruction of the continental palaeoenvironments from the late Palaeocene to Oligocene.

\section{1 | Sedimentology \& sedimentary geochemistry}

Based on lithology, thickness and geometry, sedimentary structures and fossil content, we recognized thirteen facies 
in the field (Table S2). This study was complemented by the analysis of the mineralogical components, fossil assemblages and the texture of the carbonate rocks in thin sections leading to description of sixteen microfacies (MF) (Figure 2, Supporting Information Figure S2, Figure S3 and Table S3). Individual facies and microfacies are grouped into facies associations (FA) each of which characterizes a specific depositional environment (Table S1). The facies and microfacies were deposited in alluvial plain, coastal plain, restricted subtidal-shoreface, shoal-high energy shoreface, wave-dominated outer estuarine, offshore and hypersaline evaporitic shelf environments with variable lateral settings and relationships during the regression and transgression events (Figure 3a, see Supporting Information section 2 for detailed explanation of the lithofacies and depositional environments). Differentiation of gypsum bearing facies as playa, supratidal sabkha and coastal salina settings was not always straightforward due to the lack of diagnostic sedimentary and lithological features on some exposures. This difficulty could also be due to the gradation of evaporite including depositional settings into each other, which produce similar depositional processes and facies in some cases (James \& Walker, 1992), accordingly, these type of deposition might have occurred in any of those abovementioned near coast depositional settings. However, stable oxygen and carbon isotopic composition of the carbonate rocks interlayered between gypsum beds can help to identify depositional environments when field observations are insufficient (Hudson, 1977; Nelson \& Smith, 1996). For this reason, we analysed bulk carbon $\left(\delta^{13} \mathrm{C}\right)$ and oxygen $\left(\delta^{18} \mathrm{O}\right)$ isotopic compositions of carbonates from the Mine and Aertashi sections to determine marine and continental influences, which helped with interpretations of depositional environments. (See Supporting Information section 3 for the details of the stable oxygen and carbon isotopic analysis).

\section{2 | Sequence stratigraphy}

We used different kinds of surfaces indicative of either a seaward or landward shift of the successive facies belts, that is, subaerial unconformity, transgressive surface, maximum flooding surface and basal surface of forced regression. These surfaces bound the different systems tracts, that is, lowstand, transgressive, highstand and falling stage systems tracts, composing the depositional sequences (Catuneanu, 2006 and references therein). The correlations of the surfaces between our different sections led to propose a regional stratigraphic architecture of the Tarim Basin for the Paleogene. (See Supporting Information section 4 for the details of the sequence stratigraphic analysis).

\section{3 | Biostratigraphy}

Biostratigraphic samples were collected in Paleogene marine deposits from widespread sections in the Tarim Basin
(Artashi, Kangsu and Mine sections) and Tajik Basin (Aksu and Shuldara sections; Figure 1) to constrain the age of the deposits. Samples of foraminifera, nannofossils and dinoflagellate cysts (dinocysts) were selected for age correlations. We utilize the standard microfossil zonations (Figure 8, Table S4, S5, S6, S7, S8, S9, S10, S11, S12 and S13).

\subsection{1 | Palynology}

Palynological samples (approximately $50 \mathrm{~g}$ of rock) were prepared using standard procedures at Palynological Laboratory Service, Holyhead, UK. Briefly, concentrated HCL and HF were used to dissolve carbonates and silicates respectively, followed by neutralization and sieving at $10 \mu \mathrm{m}$ to remove small particles. In addition, a few samples required short ultrasonic treatment and/or mild oxidation with $\mathrm{HNO}_{3}$. The concentrated $>10 \mu \mathrm{m}$ fraction was mounted on a microscope slide in glycerine jelly and analysed at 400 magnification under a light transmitting microscope (Olympus CX41/ Leica DMRB). For biostratigraphy, two slides were scanned entirely and for assemblage studies a minimum of 200 dinoflagellate cysts (dinocysts) were counted and 250 grains for pollen. Dinocyst taxonomy follows Fensome and Williams (2004), and Bijl et al. (2016) for Wetzellielloid species.

\subsection{2 | Calcareous nannofossils}

Smear slide preparation for calcareous nannofossils followed standard techniques (Bown \& Young, 1998) and analyses were performed using a Zeiss Axioskop 40 microscope under crossed-polarized and transmitted light at 1,250 magnification, scanning at least three transverses of each slide (ca. 600 fields of view). The nannofossils were identified following the taxonomy given in Perch-Nielsen (1985), and the Nannotax website (Young, Bown, \& Lees, ). The biostratigraphic attributions are based on the schemes proposed by Martini (1971) and Okada and Bukry (1980) and on the recognition of secondary nannofossil bioevents (e.g. Bown, 2005; Raffi, Backman, \& Pälike, 2005; Fornaciari et al., 2010; Agnini et al., 2014; Shcherbinina et al., 2016).

\subsection{3 | Foraminifera}

For the benthic foraminiferal taxonomy, we basically followed Loeblich \& Tappan (1988) at generic level. Due to the state of preservation and low abundance, identification at specific level was fairly limited. Whenever possible, benthic foraminifera species were identified mainly by following the species concepts of Cushman (1951), LeRoy (1953), Berggren and Aubert (1975) and Speijer (1994). The taxonomy and biostratigraphic attribution of planktonic foraminifera were based on Olsson, Hemleben, Berggren, and Huber (1999), Pearson et al. (2006) and Young et al. (2018). 

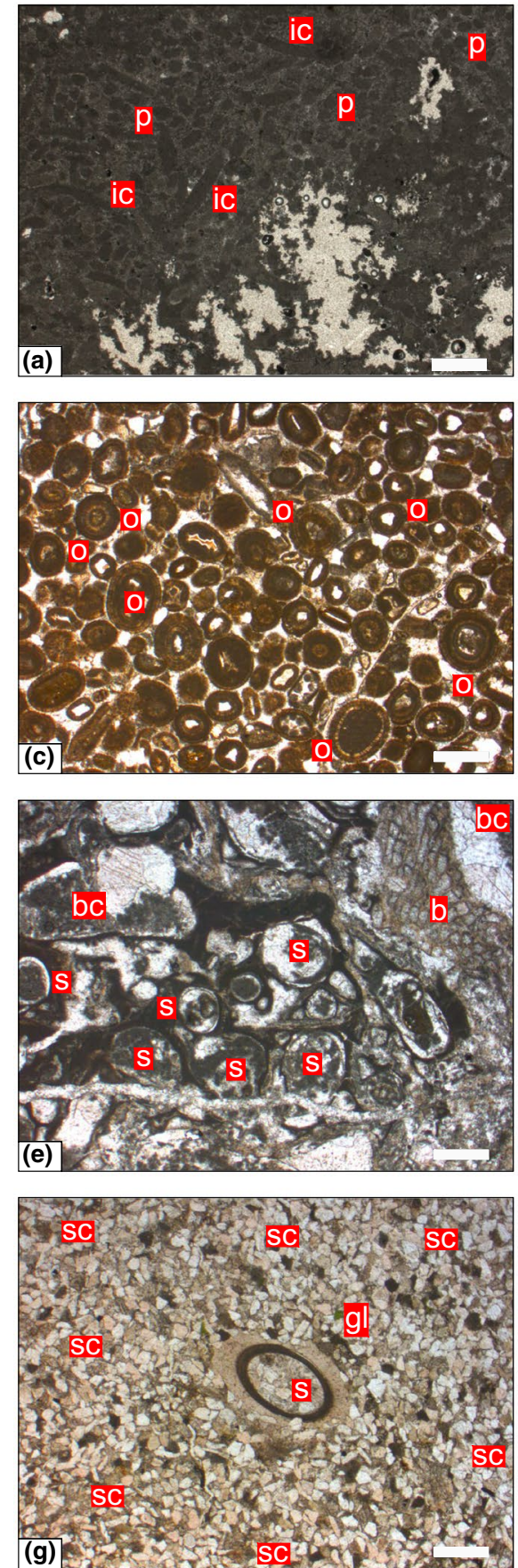
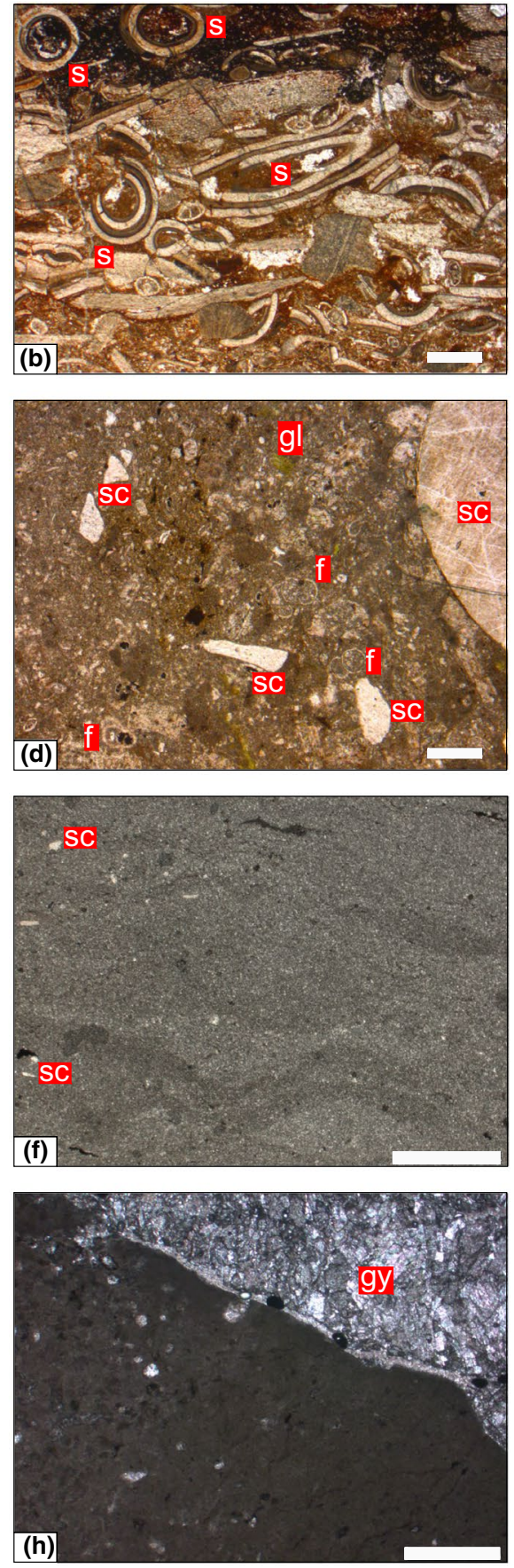

F I G URE 2 Photomicrographs of some microfacies (a) peloidal wacke-to packstone (MF3) KS15-C08; (b) serpulid packstone (MF4) AT13-TS39; (c) ooidal grainstone (MF7) AT13-TS46; (d) distal sandy allochem limestone (MF11) MI13TS24; (e) bioclastic packstone (MF6) MI13-TS02; (f) micritic mudrock (MF15) MI15-C22; (g) micritic sandstone with very rare allochems (MF16b) AT13-TS28; (h) mudstone with gypsum (MF12) MI15-C08 b: bryozoan; bc: bioclast; f: foraminifera; gl: glauconite; gs: gastropoda; gy: gypsum; ic: intraclast; o: ooid; p: peloids; s: serpulid; sc: siliciclastic, for a, b, c, d, e, g and h scale bar is $500 \mu \mathrm{m}$, for $\mathrm{f}$ scale bar is $1 \mathrm{~mm}$

\section{4 | Magnetostratigraphy}

To further constrain the age, we collected palaeomagnetic core samples $(25 \mathrm{~mm}$ in diameter) from the Laghman, Mine and Shuldara sections by using a standard cordless drill powered by rechargeable batteries and cooled by a water pump. Sampling interval ranged from 0.1 to $9.0 \mathrm{~m}$ depending on the suitability of the outcrop. All samples were oriented with a magnetic compass mounted on an orientation stage. Orientations were corrected for local declination. Samples were cut into cylindrical specimens of approximately $2 \mathrm{~cm}$ in length. Palaeomagnetic analyses were carried out in the magnetically-shielded ArcheoPalaeomagnetic Laboratory of the Faculty of Geosciences at the University of Rennes 1.

Following initial measurements of natural remanent magnetization (NRM), the specimens were thermally demagnetized in a shielded oven in 9 to 19 temperature steps of up to $680^{\circ} \mathrm{C}$. After each demagnetization step, the remanent magnetization was measured by a squid $2 \mathrm{G}$ cryogenic magnetometer as well as the bulk magnetic susceptibility to monitor mineral transformation during heating. 


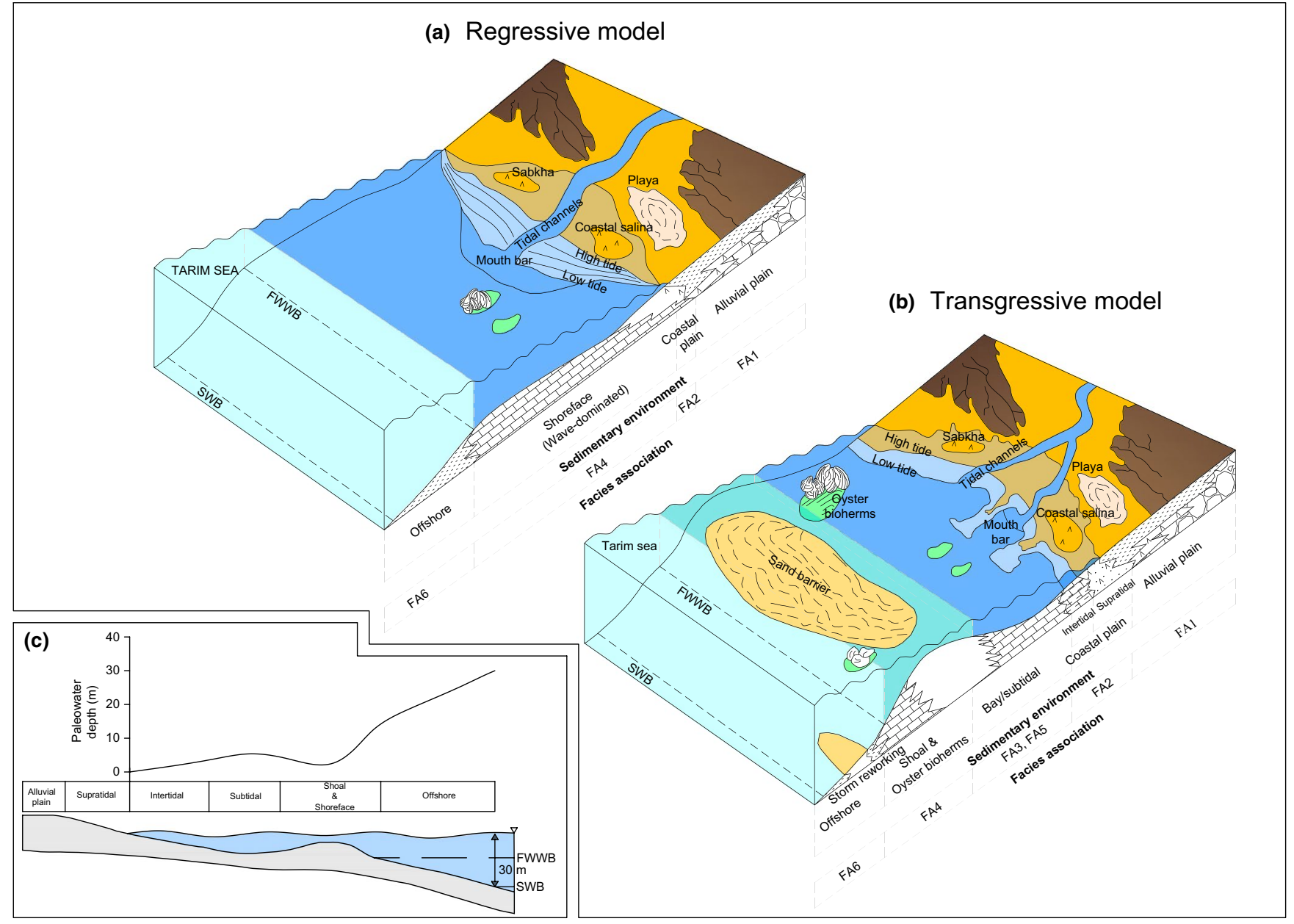

(d)
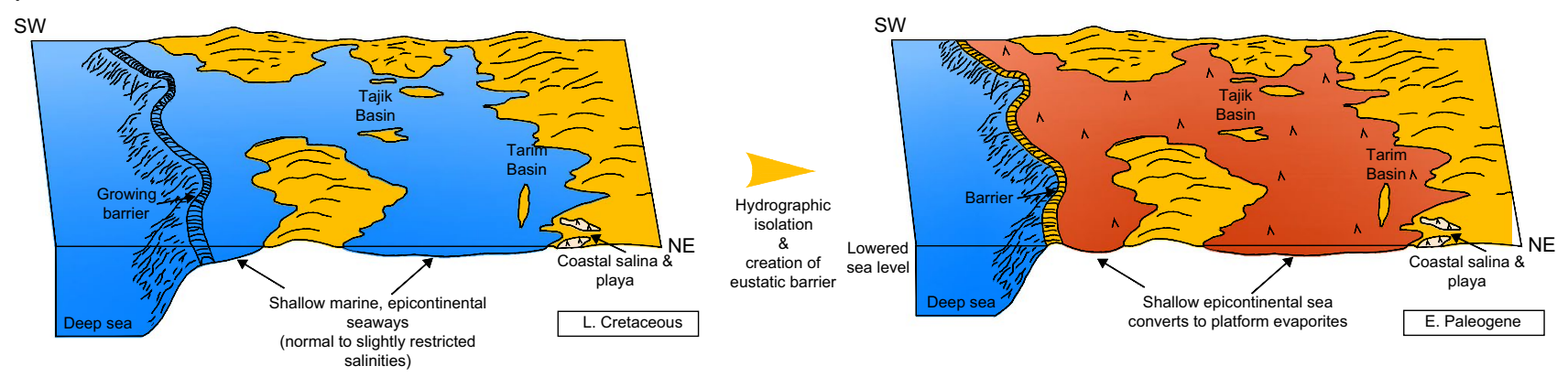

FI G URE 3 Depositional model showing the facies associations and related depositional environments during regressions (a) and transgressions (b). (c) Palaeo-water depth curve for depositional environments, depths for Fair Weather Wave Base (FWWB; between 10 and $15 \mathrm{~m}$ ) and Storm Weather Wave Base (SWB; $30 \mathrm{~m}$ ) are taken from Burchette and Wright (1992) and Flügel (2004). (d) Depositional model for the Aertashi Formation, modified from Warren (2010)

\section{4 | RESULTS}

\section{1 | Biostratigraphy}

\subsection{1 | Dinoflagellates}

\section{Tarim Basin}

The presence of Deflandrea oebisfeldensis in sample KS33 in the Kangsu section suggests that the analysed interval of the lower member of the Qimugen Formation is not older than ca. 59 Ma (Mudge \& Bujak, 1996). The Palaeocene-Eocene Thermal Maximum (PETM; ca. 55.8 Ma) is identified in sample KS36 and KS37 in the Kangsu section based on the presence of very abundant Apectodinium spp. (Crouch et al., 2001) and presence of Wilsonidium pechoricum (Iakovleva \& Heilmann-Clausen, 2007).

Upon re-examination of the samples used in Bosboom et al. (2014b) in the Mine section, we recorded Dracodinium 
rhomboideum in sample B16 at the base of the marine Bashibulake Formation in the Mine section. This marker species is restricted to C18n.2n (40.14-39.7 Ma; Eldrett et al., 2004, Bijl et al., 2013) and roughly equivalent to the Middle Eocene Climate Optimum (MECO; ca. $40 \mathrm{Ma}$ ). Presence of Dracodinium rhomboideum indicates a slightly older age for the third transgressive phase compared to the previous work of Bosboom et al. (2014b).

Based on dinocyst biostratigraphy of the samples of the Mine and Kangsu sections, we assigned a Thanetian-Ypresian age for the lower member of the Qimugen Formation and an early Bartonian age to the base of the marine Bashibulake Formation (Figures 4 and 8, see Supporting Information section 1.1 for all dinocyst analyses in the Tarim Basin).

\section{Tajik Basin}

Aksu section A Lutetian age was assigned to the upper member of the Jukar Formation, based on the presence of Adnatosphaeridium vittatum in samples AS04 and calcareous nannofossil biostratigraphy. For the Beshkent-
Lower Tochar formations in the Aksu section [correlated to the Wulagen Formation in the Tarim Basin (Bosboom et al., 2017)], the presence of H. porosa (in samples AS08AS10) indicates an age not older than C20r and not younger than C16r (Eldrett et al., 2004). Together with the results from the nannofossils biostratigraphy (see below) the age of the Beshkent-Lower Tochar formations is constrained as Lutetian-lowermost Bartonian (see Supporting Information section 1.1 for all dinocyst analyses in the Tajik Basin).

Shuldara section A Bartonian-Priabonain age is assigned for the Kushan and Sanglak formations, correlated to the 2nd, 3rd and 4th member of the Bashibulake Formation in the Tarim Basin (Bosboom et al., 2017). Few diagnostic species were present, but the short ranging taxon Dracodinium rhomboideum was recorded in sample CD10 indicating an age close to or corresponding with C18n.2n (Bijl et al., 2013; Eldrett et al., 2004). This age assignment is supported by the dinocyst assemblage, which also contains Lentinia serrata and Rhombodinium draco. We further record the appearance of Thalassiphora fenestrata in one sample

Tajik Basin

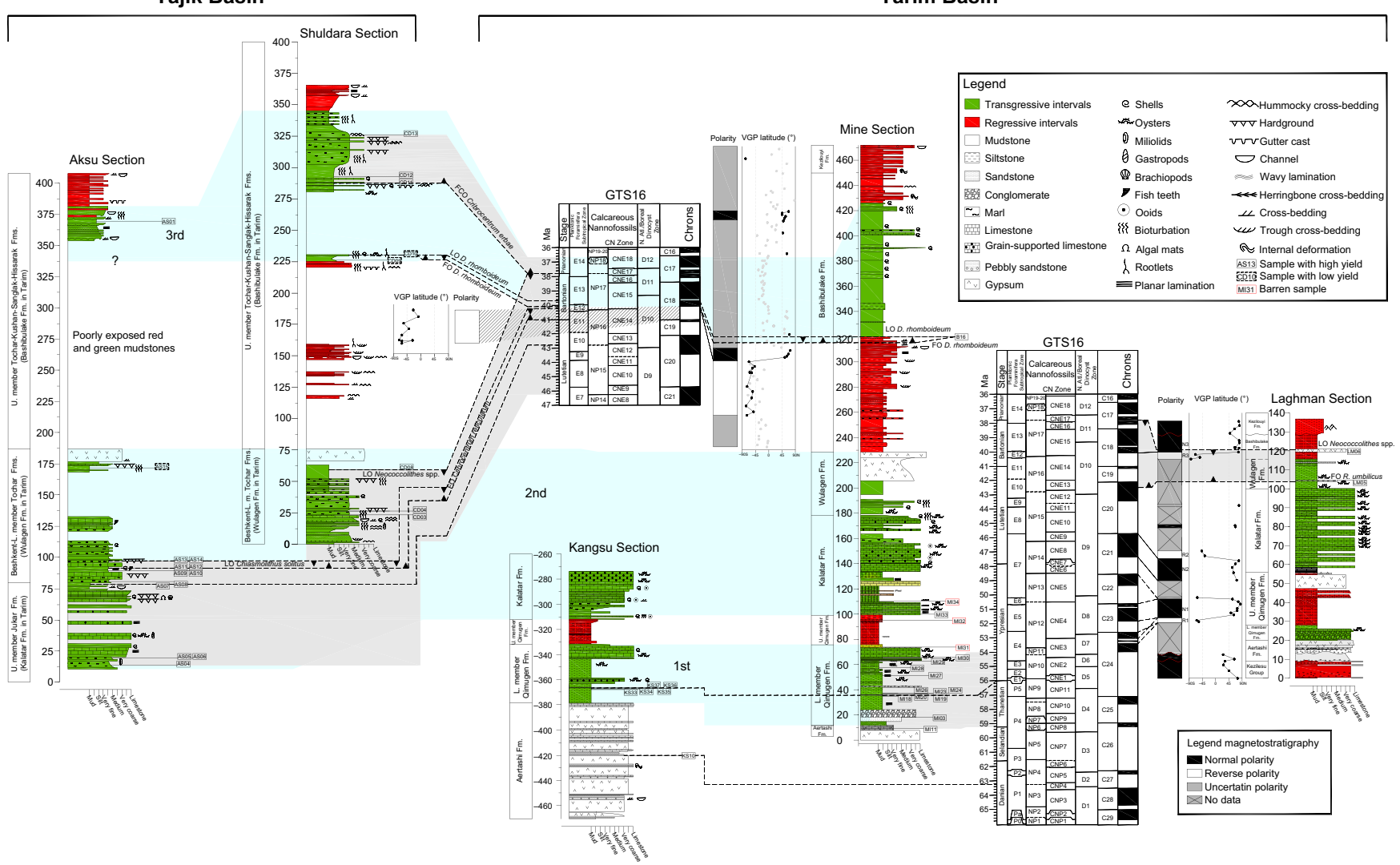

F I G U RE 4 Stratigraphic logs (in metres) of the Aksu, Shuldara (Bosboom et al., 2017), Kangsu, Mine and Laghman sections showing biostratigraphic and magnetostratigraphic correlations to the geological time scale (Ogg et al., 2016). Positive (negative) VGP latitudes represent normal (reversed) polarity indicated in black (white). The thick solid and dashed lines show preferred and other alternative magnetostratigraphic correlations to the geological time scale respectively. The age correlation based on the microfossil assemblages is shown by light grey shading corresponding dinoflagellate cyst and nannofossil zonations. FO: first occurrence of important age-diagnostic biomarker species, FCO: first common occurrence of important age-diagnostic biomarker species, LO: last occurrence of important age-diagnostic biomarker species 
(CD11), which suggests an age of NP18 (C17n.1n) or younger for the top of the analysed interval (e.g. Köthe, 2012).

\subsection{2 | Calcareous nannofossils}

Tarim Basin

A Thanetian-Ypresian age is assigned for the lower member of the Qimugen Formation in the Kangsu and Mine sections, based on the presence of several biostratigraphic markers. This notably includes the species Discoaster multiradiatus marker of the NP9 zone, ca. 57.2-55.9 Ma (samples KS34, KS36, KS37 and MI22 to MI27), Fasciculithus tympaniformis, which became extinct shortly after the Palaeocene-Eocene boundary (56 Ma, samples KS36, KS37, MI22, MI23 and MI26) and Tribrachiatus cf. bramlettei which has its first occurrence at the base of the Eocene (NP10 zone, sample KS37). A Danian age is assigned to the Aertashi Formation based on the presence of Fasciculithus spp. and F. magnicordis in sample KS10 in the Kangsu section, however a Danian-Selandian age cannot be excluded based on the Thanetian age assignment for the base of the lower member of the Qimugen Formation. A Lutetian-Bartonian age is assigned to the Wulagen Formation in view of two productive samples (LM05 and LM06) from the Laghman section based on the presence of Reticulofenestra umbilicus (first occurrence at the base of the $\mathrm{CP} 14$ zone) and the presence of the additional marker Neococcolithes spp. (last occurrence at the base of CP15 zone) (Figures 4 and 8, see Supporting Information section 1.2 for detailed calcareous nannofossil biostratigraphy in the Tarim Basin).

\section{Tajik Basin}

Aksu section The upper member of the Jukar Formation is assigned to the Lutetian based on the relatively common presence of Lanternithus sp. and in particular of L. arcanus, a species restricted to the $\mathrm{CP}$ 13b-CP 13c subzones (Bown, 2005) in samples AS04, coupled with the absence of Reticulofenestra umbilicus and Cribrocentrum reticulatum, (CP13/ NP15 zones; ca. 46.2-42.8 Ma), in agreement with previous data from the Tarim Basin (Bosboom et al., 2014a, 2011).

The samples (AS08 to AS14) collected from the BeshkentLower Tochar formations in the Aksu section, which is correlated to the Wulagen Formation in the Tarim Basin (Bosboom et al., 2017), lack $R$. umbilicus. Despite this, the formation has been tentatively correlated with the CP14a/NP16 zone (upper Lutetian-lower Bartonian; ca. 42.8-40.3 Ma) based on the absence of L. arcanus (last occurrence in the CP13c subzone) and the presence of Neococcolithes spp. and Chiasmolithus solitus, whose last occurrences are in the CP15 zone (Sheldon, 2002) and top of NP16/CP14a respectively.
Samples collected in the Upper Tochar, Kushan, Sanglak and Hissarak formations, correlated to the Bashibulake Formation in Tarim Basin (Bosboom et al., 2017), are almost barren and only at the top of the section, in a low diversity nannofossil assemblage, could the presence of Cribricentrum reticulatum be indicative of an age not older than the Bartonian (Figures 4 and 8, see Supporting Information section 1.2 for detailed calcareous nannofossil biostratigraphy in the Tajik Basin).

Shuldara section The Beshkent-Lower Tochar formations, correlated to the Wulagen Formation in Tarim Basin (Bosboom et al., 2017), are assigned to nannofossil zone CP14 ( NP16/NP17, upper Lutetian-lower Bartonian; ca. 42.8-37.8 Ma) based on the presence of Neococcolithes and Dictyococcites bisectus (samples CD03 and CD04) and the absence of Lanthernithus arcanus. The Kushan and Sanglak formations, corresponding to the 2nd, 3rd and 4th members of the Bashibulake Formation in Tarim Basin (Bosboom et al., 2017), are correlated with the lower Priabonian NP18 zone (ca. 37.8-36.7 Ma) based on the presence of Cribrocentrum reticulatum and Cribrocentrum erbae and the absence of Neococcolithes (Figures 4 and 8, see Supporting Information section 1.2 for detailed calcareous nannofossil biostratigraphy in the Tarim Basin).

\subsection{3 | Foraminifera}

A Palaeocene to early Eocene age has been assigned to the lower member of the Qimugen Formation, based on benthic foraminiferal assemblages recorded from five samples (KS33KS37, Kangsu section). Further considerations allow us to more precisely locate the position of the Palaeocene-Eocene boundary. The stratigraphic range of Anomalinoides rubiginosus (KS36) extends from Campanian to latest Palaeocene (P5 zone) (Van Morkhoven et al., 1986), thus, the level KS36 cannot be younger than latest Palaeocene in age. Since Acarinina multicamerata is regarded as an excursion taxon in the PETM interval (Guasti \& Speijer, 2008), its presence in the KS37 (E1 zone) define the position of the PalaeoceneEocene boundary between samples KS36 and KS37.

Furthermore, based on the presence of Acarinina multicamerata in the early Eocene E1 zone (MI-B22 and MI-B23, Mine section), the Palaeocene-Eocene boundary is delineated between samples MI-B21 and MI-B22 (Guasti \& Speijer, 2008) (Figures 4 and 8, see supplementary materials section 1.3 for detailed foraminifera biostratigraphy in the Tarim Basin).

\section{2 $\quad$ Pollen assemblages}

New palynological samples were taken from the Mine and Kangsu sections, but most contained only a few palynomorphs, precluding a quantitative analysis of the material. One productive sample (MI03, numbering 250+ grains) 
could be counted from the Thanetian-Ypresian lower member of the Qimugen Formation (Mine section) and contained a diverse palynoflora including abundant Ulmipollenites, Inaperturopollenites, Graminidites, Sparganiaceaepollenites and rare Alnipollenites, Ephedripites, Podocarpidites and Chenopodipollis. Other samples from the Palaeocene-Eocene containedinfrequent grains of Ephedripites, Steevesipollenites, Polypodiaceaesporites, Nitrariadites-Nitraripollis, Cicatricosisporites and Lophotriletes.

Taken together with the pollen assemblages examined by Wang et al. (1990), late Palaeocene and early Eocene continental environments associated with the Tarim Basin were semi-arid and temperate. The middle Eocene was also semiarid but warmer, and growth of the steppe-desert biome in the late Eocene reflects intensifying aridification in continental Asia following the long-term westward retreat of the protoParatethys Sea (Bosboom et al., 2014c; this paper). These data may also reflect a decrease in seasonality between wetter/cooler winters and dryer/hotter summers. The seasonal moisture influx from the nearby proto-Paratethys during the winter westerlies previously evidenced by Bougeois et al. (2018) is expected to decrease as the sea retreats and thereby seasonality in precipitation regime also decreases. Finally, rapid cooling at the Eocene-Oligocene Transition (EOT) is consistent across the Xining and Tarim basins, evidenced by a rapid increase in microthermal-mesothermal Pinaceae pollen (see Supporting Information section 1.4 for detailed analysis on pollen assemblages).

\section{3 | Magnetostratigraphy}

\subsection{1 | Thermal demagnetization}

The gypsiferous red mudstones of the upper member of the Qimugen Formation display higher initial Natural Remanent Magnetization (NRM) intensities on the order of $10^{-2} \mathrm{~A} / \mathrm{m}$. Upon thermal demagnetization, after removal of secondary normal overprint at $200-300^{\circ} \mathrm{C}$, the trajectories of the remanent magnetization show a linear decay up to $\sim 580^{\circ} \mathrm{C}$ interpreted as a magnetite-type behaviour, and then up to $\sim 670^{\circ} \mathrm{C}$ indicating the additional presence of haematite (Figure 5a). The carbonates of the Kalatar Formation are characterized by low initial NRM intensities on the order of $10^{-4}-10^{-5} \mathrm{~A} / \mathrm{m}$. A secondary normal overprint is removed by demagnetization up to $300^{\circ} \mathrm{C}$. This is followed by a linear decay towards the origin for the carbonates with relatively higher initial NRM $\left(10^{-4} \mathrm{~A} / \mathrm{m}\right)$ (Figure $\left.5 \mathrm{~b}\right)$. Carbonates with relatively low magnetization values $\left(10^{-5} \mathrm{~A} / \mathrm{m}\right)$ yielded erratic paths after $400^{\circ} \mathrm{C}$ (Figure 5b) such that no interpretable directions could be obtained from these samples. Initial NRM intensities of the red mudstones of the Wulagen Formation are on the order of $10^{-3} \mathrm{~A} / \mathrm{m}$. Following progressive removal of secondary normal overprints mostly between 250 and $410^{\circ} \mathrm{C}$, gypsiferous red mudstones of the Wulagen Formation show a linear decay up to $\sim 670^{\circ} \mathrm{C}$ (Figure 5c). Similarly, specimens of the red mudstone of the Bashibulake Formation and the red siltstone of the Keziluoyi Formation display higher initial intensities (on the order of $10^{-3}$ and $10^{-2}$ respectively) and show a decay up to $\sim 670^{\circ} \mathrm{C}$ (Figure 5e). They are also interpreted to represent a combination of magnetite and haematite.

\subsection{2 | Characteristic Remanent Magnetization (ChRM) directions}

ChRM directions were calculated by application of principal component analysis (Kirschvink, 1980) on orthogonal demagnetization plots. The line-fits were applied on a minimum of four temperature steps. In rare cases of clustered directions with a clear normal or reverse orientation but no clear decay, line-fits were anchored to the origin. Most samples have maximum angular deviation (MAD) values of less than $10^{\circ}$. However, MAD values up to $30^{\circ}$ were accepted if the polarity for the samples was evident. For a few samples with no linear decay, but a clear demagnetization path along a great circle, great circle ChRM analysis (McFadden \& McElhinny, 1988) was performed. Virtual geomagnetic poles (VGPs) were calculated from the ChRM directions (Figure 6). The VGPs cluster into two antipodal groups: either normal or reverse. Outliers having a VGP of more than $45^{\circ}$ from the means of these two clusters were iteratively removed and were not used for further analysis (Figure 6). The mean normal and reverse ChRM directions were respectively calculated from these two clusters by using Fisher statistics (Fisher, 1953).

\subsection{3 | Correlation to the geomagnetic polarity time scale}

Magnetic polarity zones were defined by at least two consecutive VGP latitudes of the same polarity. Due to the large sampling gaps in Laghman section (because of outcrops or lithologies unsuitable for palaeomagnetism), correlation of a continuously recorded polarity zonation to the geomagnetic polarity time scale (GPTS; Ogg et al., 2016) is prevented. Nevertheless, the combination of available palaeomagnetic polarity indications with biostratigraphic constraints from the sections (Bosboom et al., 2014a; Wan et al., 2014 and this study) partially restricts possible correlations. Therefore, instead of matching a series of alternative correlations to the GPTS, we attempted to define reasonable correlations to the GTS for the Laghman section based on the biostratigraphic results (Bosboom et al., 2014a; Wan et al., 2014 and this study).

The interval including samples LM06 and LM05 in Laghman section correlates to the CP14 zone (corresponding to the NP16/NP17) based on the nannofossil assemblage (Figure 4). This implies that the top normal interval zone (N3) around 120 metres in the Bashibulake and Wulagen 


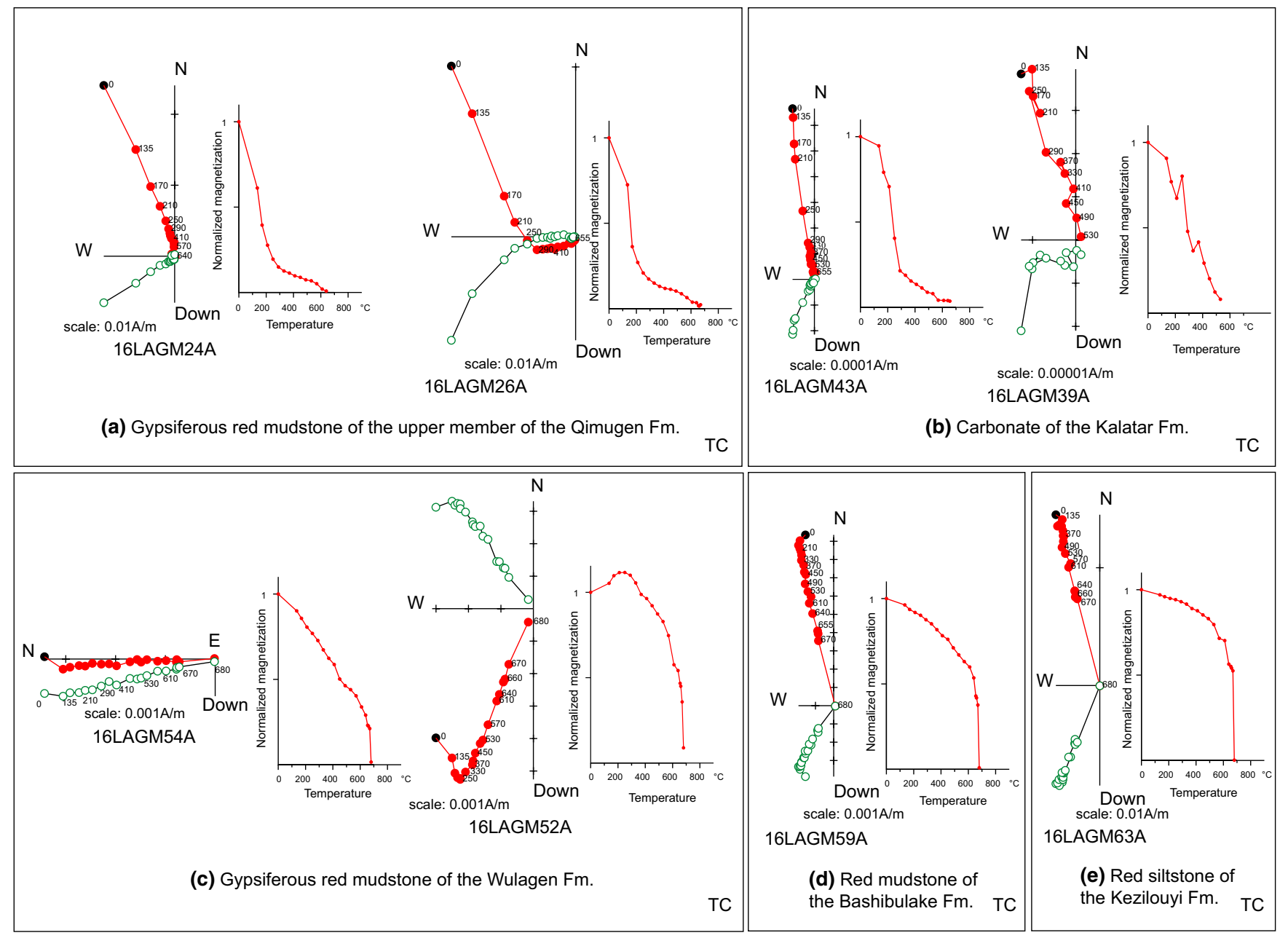

F I G U RE 5 Orthogonal plots showing the thermal demagnetization behaviours and decay of intensities of representative specimens of (a) gypsiferous red mudstone of the upper member of the Qimugen Formation, (b) carbonates of the Kalatar Formation, (c) gypsiferous red mudstone of the Wulagen Formation, (d) red mudstone of the Bashibulake Formation, (e) red siltstone of the Kezilouyi Formation in tilt-corrected (TC) coordinates. Numbers next to symbols indicate temperature of demagnetization steps in ${ }^{\circ} \mathrm{C}$

F I G URE 6 Equal-area plots of the ChRM directions indicated separately for in situ (IS) and tilt-corrected (TC) coordinates. The plot shows the least square fits and their Fisher means for normal $(\mathrm{N})$ and reversed (R) polarities. ChRM directions rejected after $45^{\circ}$ cut-off are shown in red. Solid symbols indicate downward directions, and upward directions are shown as open symbols. The dashed ellipse indicates the alpha95 confidence limit of the Fisher mean directions. D: mean declination and I: mean inclination, n: number of accepted direction, $\alpha 95$; angular radius of $95 \%$ confidence on mean direction
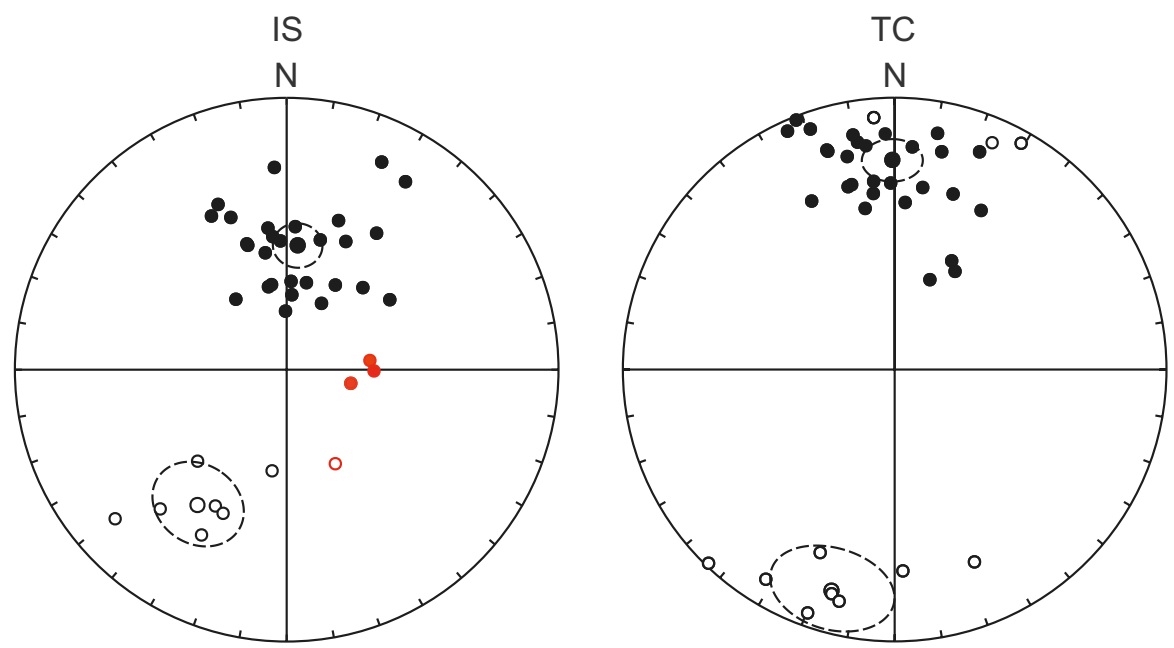

TC after $45^{\circ}$ cut-off

$\mathrm{N}: \mathrm{D}=359.4^{\circ} ; \mathrm{I}=23.2 ; \alpha 95=7.6 ; n=31$ (31)

$\mathrm{R}: \mathrm{D}=195.9^{\circ} ; \mathrm{I}=-16.5 ; \alpha 95=15.2 ; n=8$ (8) 
formations should correlate to $\mathrm{C} 18 \mathrm{n}$ (which is the longest normal chron in this interval) whereas the reverse interval below (R3), containing the transitional facies, correlates unambiguously to $\mathrm{C} 18 \mathrm{r}$ (Figure 4). This correlation implies that the age of the 2nd Paleogene regression is within C18r (41-40.1 Ma) similar to the Aertashi section (Bosboom et al., 2014a). It is known from both previous studies (Bosboom et al., 2014a; Wan et al., 2014) and this study (Figure 4) that the Kalatar Formation correlates to the CP13 zone ( NP15 Zone) (Lutetian) based on the macro- and microfossil assemblage. Because NP15 zone span the interval between ca. 46.2-42.8 Ma and C20r is the only reverse chron during this duration, the reverse interval zone (R2) around 62 metres in the Kalatar Formation should be correlated to C20r. It follows that the normal interval zone (N2) below C20r is correlated to $\mathrm{C} 21 \mathrm{n}$. This constrains the age of the upper member of the Qimugen to Kalatar Formation boundary to within C21n (47.3-45.7 Ma). The youngest possible age for the top of the lower member of the Qimugen Formation is constrained as ca. $54 \mathrm{Ma}$ based on the stratigraphically highest productive sample (MI29). Therefore, the normal (N1) and reverse (R1) intervals around 30-40 $\mathrm{m}$ in the upper member of the Qimugen Formation should be younger than $54 \mathrm{Ma}$. Two alternative correlations to the GPTS can be proposed for the reversal (R1) around $30 \mathrm{~m}$ at the base of the upper member of the Qimugen Formation. It may either correlate to the top of chrons C23r (51.8 Ma) or the top of C24n.2r/C24n.1r (53.2 Ma).

The red clastics at the base of the Bashibulake Formation in the Mine section have yielded some interpretable directions guided by the biostratigraphic constraints (this study) (Figure 4). The first productive sample (B16) in the marine deposits above the red clastics is dated to C18n.2n (40.1439.7 Ma). Given this constraint, the normal interval zone and the long reversed interval zone below should correlate to C18n.2n (40.1-39.7 Ma) and C18r (41.0-40.1 Ma) respectively (Figure 4). Similarly, in Shuldara section in Tajik Basin, the observed long reversed interval zone in the red clastic deposits of the Upper Tochar-Kushan-Sanglak-Hissarak formations (corresponding to the Bashibulake Formation in Tarim Basin) should correlate to the $\mathrm{C} 18 \mathrm{r}$ (41.0-40.1 Ma) based on the sample CD10, which is constrained to C18n.2n (40.139.7 Ma) (Figure 4).

\section{4 | Sequence stratigraphy overview}

Based on our sequence stratigraphic analysis, the studied interval including the three Paleogene sea incursions is divided into four depositional sequences (S) along the western Tarim Basin (Figure 7). Facies/microfacies analyses indicate that the transgressive intervals are represented by offshore, shoal, subtidal/bay and intertidal facies bearing distinct fossil assemblages of bivalves, foraminifera, calcareous nannofossils, dinoflagellate cysts and serpulids. The regressive intervals consist mostly of alluvial plain (fluvial and lake) and coastal plain (supratidal) facies preserving fewer (only some bivalves) or no fossils.

After the deposition of the Aertashi Formation in a restricted environment, the first Transgressive Surface (TS) is identified at the base of the first Transgressive Systems Tract (TST.1.1, Figure 7) represented by the boundary between the Aertashi and Qimugen formations. This is at odds with Zhang et al. (2018) interpreting the start of the first transgression at the base of the Aertashi Formation despite the absence of solid evidence for a transgressive event. The first sequence (S1) starts with a Lowstand Systems Tract below, within the Aertashi Formation (Figure 7). Therefore, we rather interpret the deposition of the Aertashi Formation as part of regressive phase, which had already started during the deposition of the underlying regressive Tuyiluoke Formation. The regression at the top of the lower member of the Qimugen Formation is interpreted as a forced regression displaying a typical shoreline regression driven by a net base level fall (relative sealevel lowering) represented by the progradational strata in a Falling Stage Systems Tract (FSST.1.1, Figure 7).

The next sequence (S2) starts with the transitional to continental deposits of the upper member of the Qimugen Formation marked by a Lowstand Systems Tract (LST.2.1) representing the 1st Paleogene regression. The next transgression starts with a transgressive surface represented by the boundary between the Qimugen and Kalatar formations and followed by the building up of a carbonate ramp system starting with TST.2.1 (Figure 7). It is followed in the Kalatar Formation by a Highstand Systems Tract (HST.2.1) at the top of S2 which is interpreted as a normal regression displaying typical shoreline regression driven by sediment supply during the late stage of a base level rise.

The next sequence (S3) is represented in the upper part of the Kalatar and most of the Wulagen formations. The sedimentary architecture of S3 expresses localized drowning of the carbonate ramp system previously developed during the end of S2 in the lower part of the Kalatar Formation. There are clear differences in the expression of S3 between the northwestern and southwestern Tarim Basin. In the north, S3 develops exclusively as a well-developed carbonate ramp system along the southern Tian Shan where the Mine and Kangsu sections are located. In contrast, S3 is more clastic-dominated in southwestern Tarim with higher accumulation after SB2, as observed in the Aertashi section (Figure 7) along the eastern Pamir during deposition of the Kalatar Formation as also documented in Yang et al. (2014). This suggests a more proximal position of the south Tarim Aertashi section on the ramp system recording the increase in siliciclastic deposition after SB2. In addition, fluctuations between TST.3.2 and TST.3.4 observed in the Aertashi section to the south are not recorded in the Mine section to the 
NW

SE
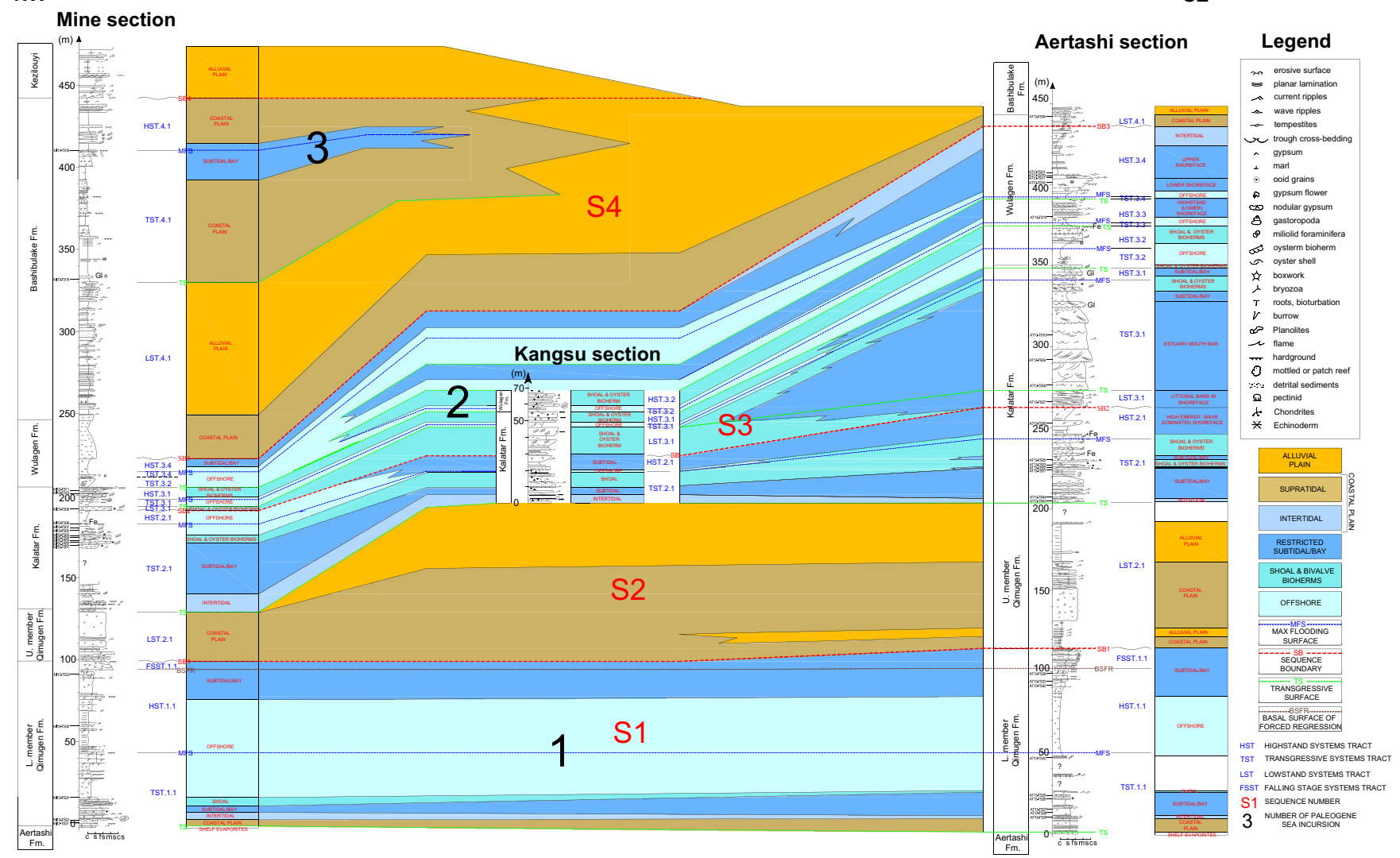

F I G U R E 7 Stratigraphic logs of the Mine, Kangsu and Aertashi sections showing sequence stratigraphic interpretations and correlations. Correlation of the identified key bounding surfaces (i.e. SBs, MFs, TSs, BSFR) between the Mine, Kangsu and Aertashi sections enabled us to propose a regional stratigraphic architecture for the Tarim Basin. Four types of systems tracts have been interpreted; LST, TST, HST and FSST (see legend of the figure and section 4 of the supplementary materials for the details)

north where offshore deposition continued. Together this can be explained by a more distal (outer) position on a ramp for the northern Mine and Kangsu sections compared to the southern Aertashi section during these systems tracts. In S3, the next Highstand Systems Tract.3.2 (HST.3.2), recognized in the Kangsu and Aertashi sections, and HST.3.3, recognized in the Aertashi section, are interpreted as 'internal' Highstand Systems Tract (Catuneanu, 2006), where carbonate production is in balance with slow continuous sea level rise (Figure 7). In contrast, at the top of $S 3$, represented by the top of the Wulagen Formation, HST.3.4, recognized both in the north Tarim Mine and south Tarim Aertashi sections, is interpreted distinctly as the 'final' highstand systems tract (Catuneanu, 2006) marking the return to a siliciclastic-dominated system indicating a regional normal regression displaying shoreline regression driven by sediment supply during the late stage of a base level rise.

S4 is observed only in the north Tarim Mine section where it includes the deposits of the 3rd Paleogene sea incursion that are mostly continental and transitional with relatively thinner marine deposits only observed near the maximum flooding surface (MFS; Figure 7). This implies a less extensive sea incursion only affecting the outer part of the shelf located in north Tarim.

\section{5 | Age control overview}

\subsection{1 | Aertashi Formation: ca. 63-59 Ma restriction event}

Our biostratigraphic results clearly indicate a Danian (NP4 zone ca. 63.2-61.5 Ma based on the nannofossil assemblage) age for the Aertashi Formation. A Danian age is in agreement with most previous studies (Chinese Bureau of Stratigraphy, 1981; Hao et al., 1982; Jia et al., 2004; Tang et al., 1989; Wan et al., 2014). In particular, it refines the previous early to middle Palaeocene age assignment of Mao and Norris (1988) and Wang et al. (1990) based on dinoflagellate cysts and pollen grains. Yet, the age extent of the Aertashi Formation depends on the age assignment of the underlying Tuyiluoke and overlying Qimugen formations.

A Danian age has been generally assigned to the Tuyiluoke Formation, based on the presence of foraminiferal assemblages including genera of Nonion, Cibicides, Cibicidoides, Quinqueloculina (Guo, 1990; Hao \& Guo, 1990 and Hao et al., 2001). Yet, the presence of these genera in the Cretaceous did not enable to restrict the Tuyiluoke Formation to the Danian. However, a Danian age may be confirmed by reports 
of the Cretaceous-Paleogene (K/Pg; $66 \mathrm{Ma}$ ) boundary, $1.4 \mathrm{~m}$ stratigraphically above the base of the Tuyiluoke Formation in Aertashi ('Altax') section based on the alleged presence of an iridium anomaly and the associated trace element, rare earth element anomalies and anomalous change of carbon and oxygen isotopes (Guo, 1990; Tang et al., 1992; Ye et al., 1992). Together this suggests a Danian age for the Tuyiluoke Formation and therefore that the base of the Aertashi Formation is within the Danian.

Above the Aertashi Formation, the age of the base of the lower member of the Qimugen Formation is well constrained with an oldest possible age of ca. $59 \mathrm{Ma}$ by our biostratigraphic assemblages which is corroborated by recent zircon U-Pb dating of a tuff (Zhang et al., 2018) (see next section). However, we cannot exclude the Aertashi Formation extends into the Selandian (61.6-59.2 Ma). Based on these constraints, we can estimate the age of the Aertashi Formation, representing a major regional restriction event (see discussion below), as Danian (ca. 63.2-61.5 Ma), possibly extending up into the Selandian (61.6-59.2 Ma) (Figure 8).

\subsection{2 | Qimugen Formation: ca. 59-52 Ma, first Paleogene sea incursion}

As previoulsy mentioned, our age determination for the base of the lower member of the Qimugen Formation (oldest possible age of ca. $59 \mathrm{Ma}$ ) is also supported by the age constraint based on zircon $\mathrm{U}-\mathrm{Pb}$ dating of a tuff reported by Zhang et al. (2018). They reported the weighted mean $\mathrm{U} / \mathrm{Pb}$ age of $57.58 \pm 0.49 \mathrm{Ma}(1 \sigma, n=30)$ yielded from zircon crystals in the tuff layer occurring $19 \mathrm{~m}$ above the base of the Qimugen Formation. Therefore, the boundary between the Aertashi and Qimugen formations can be further constrained to within $59 \mathrm{Ma}$ and $57.5 \pm 0.5$ Ma providing an age for the 1st transgression at ca. 59-57 Ma. These assignments update the age of the lower member of the Qimugen Formation as Thanetian-Ypresian which was reported previously as Selandian-Thanetian (Wan et al., 2014) and Thanetian (Zhang et al., 2018) (Figure 8). The age of the 1 st regression represented by the boundary between the lower and upper members of the Qimugen Formations is here determined as ca. 53-52 Ma (C23r-C24n.1r).

\subsection{3 | Kalatar and Wulagen formations: ca. 47-41 Ma, second Paleogene sea incursion}

The age of the boundary between the upper member of the Qimugen and Kalatar formations (corresponding to the onset of the 2nd Paleogene marine transgression in the Western Tarim basin) is determined as ca. 46-47 Ma (within C21n). This constrains the base of the Kalatar Formation to the early Lutetian which is in agreement with the previously suggested age of Wan et al. (2014) but at odds with the previously attributed late Ypresian age by Zhang et al. (2018) (Figure 8). The top of the Wulagen Formation, recording the regression related to the 2 nd Paleogene sea incursion, is dated here more precisely at ca. 41-40 Ma (within C18r) in both Tarim and Tajik basins confirming previous ages by Bosboom et al. (2017, 2014a, 2014b).

\subsection{4 | Bashibulake Formation: ca. 39.7- 36.7 Ma, third Paleogene sea incursion}

The youngest age for the onset of the 3rd Paleogene sea transgression is determined as ca. $39.7 \mathrm{Ma}$ (within C18n.2n) in the Tajik and Tarim basins based on our biostratigraphic and magnetostratigraphic results. Together with its regression, the last sea

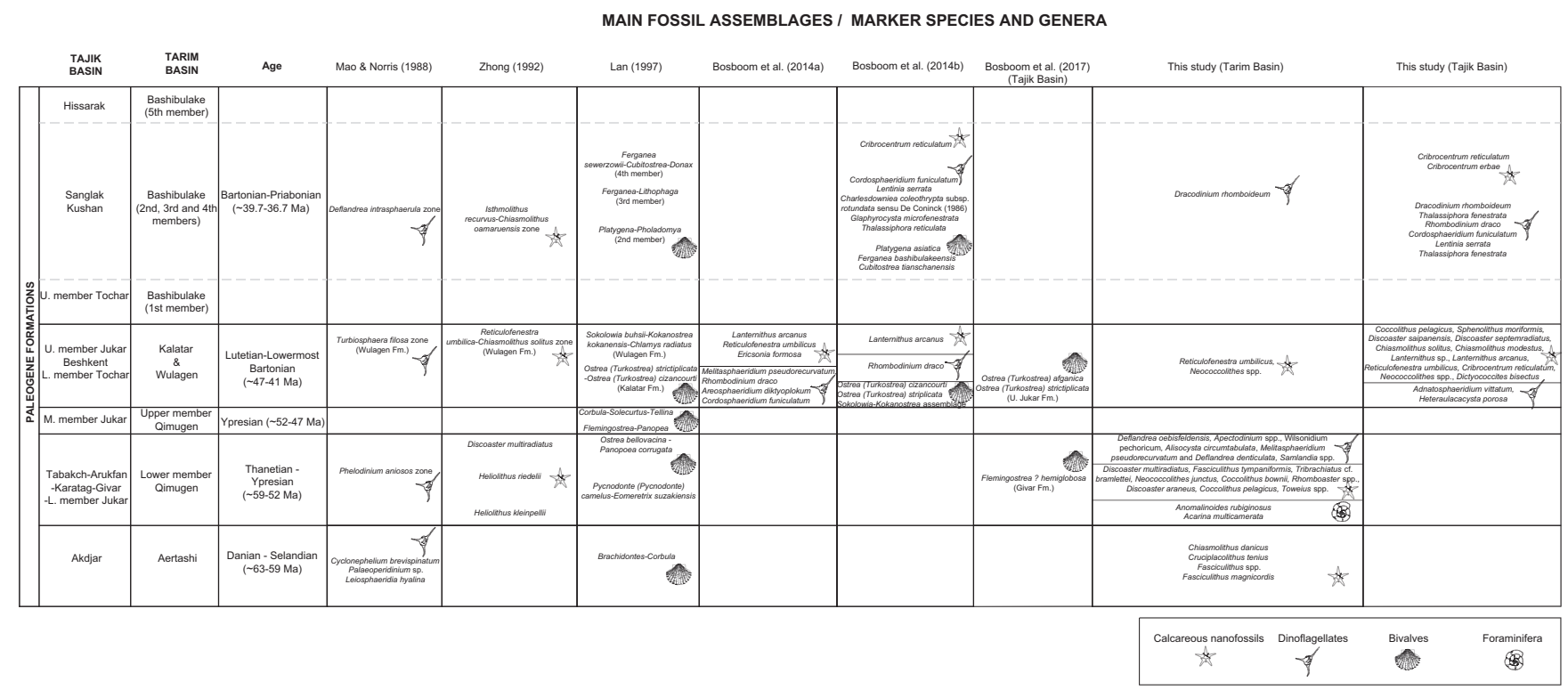

F I G U RE 8 Depositional ages for the Paleogene formations in the Tarim and Tajik basins based on the fossil assemblage and marker fossil 
incursion in the Tarim and Tajik basins is tightly bracketed within 39.7-36.7. This new age constraint updates the previous age estimate of Bosboom et al (2014b) where the incursion was dated to within near top $\mathrm{C} 17 \mathrm{n} .2 \mathrm{n}$ to base $\mathrm{C} 16 \mathrm{n} .2 \mathrm{n}$ ( 38.0 to $36.5 \mathrm{Ma}$ ).

In summary, these new age constraints and ages reported by Bosboom et al. (2017, 2014a, 2014b) now provide a solid Paleogene chronostratigraphic framework for the protoParatethys Sea incursions in Central Asia and supersede the previous lower resolution (Wan et al., 2014; Wang et al., 2014; Zhang et al., 2018) and contradictive works (Sun \& Jiang, 2013; Sun et al., 2016).

\section{5 | DISCUSSION}

\section{1 | Driving mechanisms and Palaeogeography}

Different driving mechanisms causing the relative sea level fluctuations of the Proto-Paratethys were proposed in previous studies. These include tectonism and associated basin overfilling usually related to the India-Asia collision (Burtman, 2000; Burtman \& Molnar, 1993), eustatic sea level changes (Dupont-Nivet et al., 2007; Sobel \& Dumitru, 1997) and the combined effects of both tectonism and eustasy (Bosboom et al., 2017, 2014a, 2011; Zhang et al., 2018). However, age control was so far insufficiently resolved to provide unequivocal determination of the controlling factors especially on the 1st and 2nd Paleogene sea incursions.
To elucidate these potential driving mechanisms, we used the refined age constraints and palaeoenvironmental interpretations to construct a relative sea level curve and subsidence curves based on the Mine and Aertashi sections (Figures 9 and Figure S5). The relative sea level curve was generated by assigning palaeo-water depths to the defined facies/microfacies based on their relative positions to the Fair Weather Wave Base (FWWB) and Storm Wave Base (SWB; Figures 3c and Figure 9). The depth of FWWB was assumed as between 10 and $15 \mathrm{~m}$ and SWB as $30 \mathrm{~m}$ (Burchette \& Wright, 1992; Flügel, 2004). It should be noted that assigned palaeo-water depth values for the facies/microfacies may not be accurate, however, their relative positions to each other, FWWB and SWB provide insight regarding the relative sea level change during the Paleogene sea incursions in the Tarim Basin. The changes in palaeo-water depths were used along with the subsidence curves to derive implication on potential driving mechanisms such as eustatic/ tectonic events and related sediment supply.

To estimate the Paleogene palaeogeographic evolution of the proto-Paratethys Sea, the refined age constraints and detailed palaeoenvironmental interpretations are combined with successive palaeogeographic maps based on an extensive review (Figure 12). Regional coastlines and depositional environments during the maximum Paleogene sea advances and retreats were drawn based on the results of this study and integrated with existing literature. The updated palaeo-reconstructions of Poblete et al. (2017) integrating continental reference points, palaeotopography and shorelines were updated with data from the Darius project (Barrier et al., 2018),

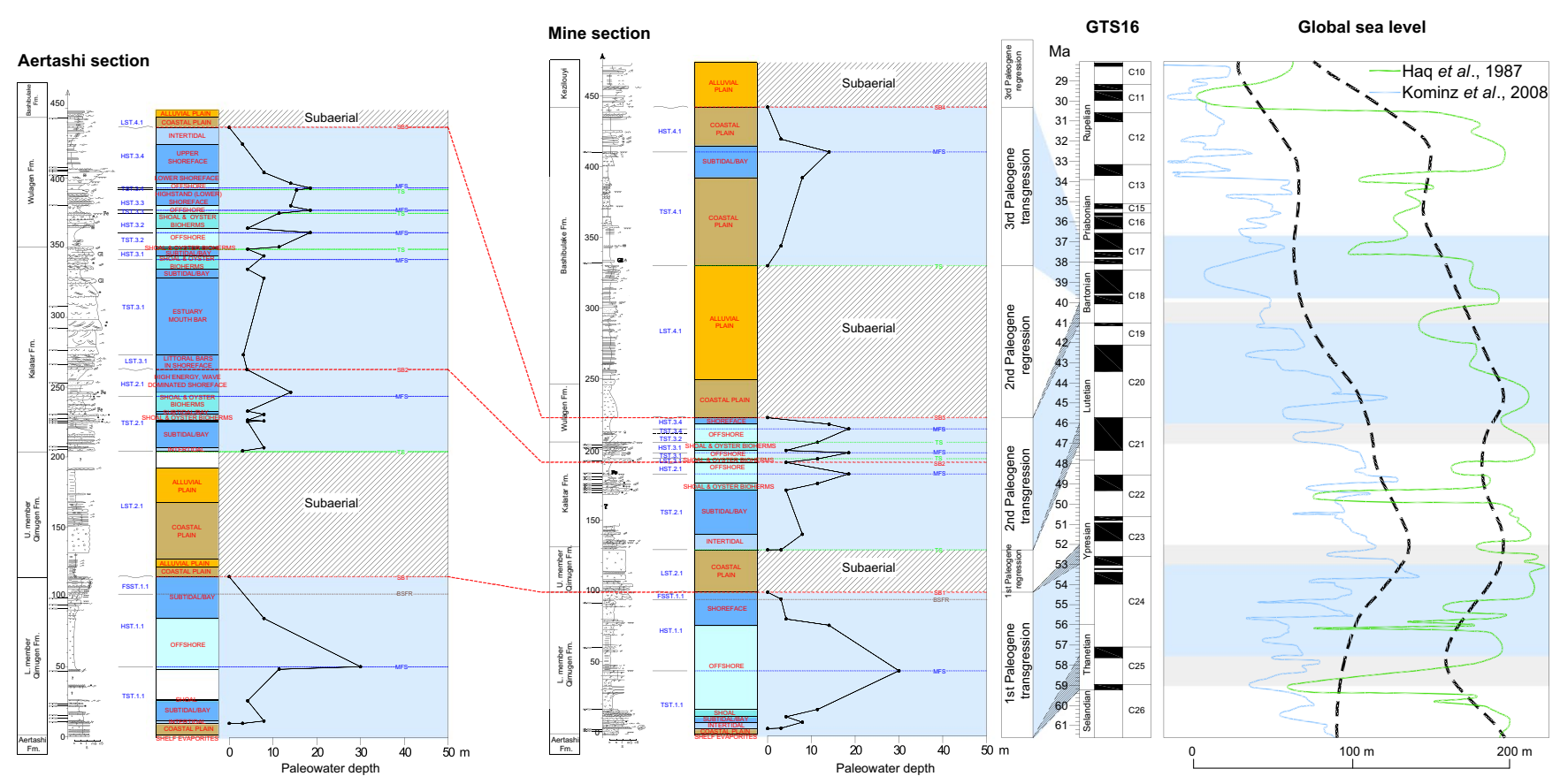

F I G U R E 9 Palaeo-water depths \& inferred relative sea level curves for the Aertashi and Mine sections compared to the global sea level curve of Kominz et al. (2008) and Haq et al. (1987). The blue shaded areas highlight the sea incursions, which have been accurately dated in this study. Grey shaded parts indicate possible age interval for the onsets of transgressions and regressions 
Peri-Tethys atlas (Dercourt et al., 2000), the compilation of Bosboom et al. (2017) and palaeogeographical changes in the Turgai Strait and West Siberian Sea were drawn based on Radionova et al. (2003), Akhmetiev and Beniamovski (2009), Akhmetiev et al. $(2012,2010)$.

\subsection{1 | Regional restriction event (ca. 63 to $59 \mathrm{Ma})$}

Both in the Tarim and Tajik basins, the interval between ca. $63 \mathrm{Ma}$ and ca. $59 \mathrm{Ma}$ is represented by a major regional restriction event marked by evaporitic deposition in the exceptionally thick Aertashi Formation in the SW Tarim Basin and the equivalent thinner correlative Akdjar Formation in the Tajik Basin. This regional restriction event is interpreted to result from a hydrographic isolation from the open sea by an exposed barrier composed of shoals and (rudist) build-ups due to a relative sea level fall at the end of Cretaceous (Figure 3d). There are several lines of evidence to support this inference. (a) The long-term elevated sea levels of Cretaceous greenhouse times would have enabled continuous platform-edge rudist build-ups and shoals to form and grow as platform-edge barriers. (b) The occurrences of rudist bioherms have been reported both in Tajik and Tarim basins and even further west in Uzbekistan (Scott et al., 2010). (c) With the subsequent sea level fall, well established at the end of Cretaceous period, these barriers most likely would have been subaerially exposed, hydrographically isolating the back-barrier part of the platform/shelf with limited marine seepage supplying water for the deposition of the evaporites (Warren, 2010). (d) The presence of a widespread uppermost Cretaceous unconformity evidencing subaerial exposure within the western Tajik Basin was reported by Sobel (1995 and references therein). (e) Similar formation of platform evaporites is common, reported from the Middle East (Jurassic Hith Anhydrite), Saudi Arabia, Qatar and the Emirates (Permian Khuff Anhydrite), Gulf of Mexico (Cretaceous Ferry Lake Anhydrite), West Texas and New Mexico (Permian San Andres Fm. and equivalents) and Australia (Cambrian Red Heart Dolomite and equivalents) (Warren, 2010 and references therein). A similar model for the isolation of the Tarim basin during the deposition of the Aertashi evaporites has been proposed by Zhang et al. (2018), yet driven by a tectonic barrier related to far-field effects at the onset of the India-Asia collision. However, the onset of the deposition of the Aertashi evaporites is now constrained to NP4 zone ca. 63.261.5 Ma (see previous section) which predates even the oldest estimates for the India-Asia collision onset such as $59 \pm 1 \mathrm{Ma}$ by $\mathrm{Hu}$ et al. (2016). In addition, the presence of thick gypsum deposition (Akdjar Formation) west of Pamir in the Tajik Basin, makes the tectonic barrier hypothesis unlikely. The tectonic hypothesis was supported by the presence of conglomerates found locally at the base of the Aertashi Formation in the Wuyitake section (Sobel, 1995; Bershaw et al., 2012) and in the Akqiy section of Tarim Basin (Zhang et al., 2018). However, these conglomerates $(<100$ metre-thick) can equally relate to channel extension during the sea-level fall with the braid-plain extending seaward resulting in more extensive fluvial deposition (Blum \& Törnqvist, 2000).

\subsection{2 | 1st sea incursion (ca. 59 Ma to 53- $52 \mathrm{Ma})$}

This represents the largest Paleogene sea incursion with a maximum water depth based on our relative sea-level curve represented by the offshore facies and microfacies of the lower member of the Qimugen Formation (Figure 9). Consistently, the maximum eastward extent of the Proto-Paratethys Sea was also reached during this 1st Paleogene sea incursion (e.g. Burtman, 2000) (Figure 12). During subsequent sea incursions, the extent and palaeo-water depths were progressively smaller until the ca. 37 Ma sea retreat out of the Tarim and Tajik basins (Bosboom et al., 2014b).

The 1st Paleogene sea incursion at ca. 59 Ma appears coeval with the Thanetian transgression in the northern Peri-Tethys sedimentary provinces (Radionova et al., 2003) (Figure 12) and the onset of a long-term global sea level high (black dashed lines in Figure 9) suggesting eustatic forcing of the 1st sea incursion. Subsequent Thanetian-Ypresian short-term global sea level fluctuations (blue curve on Figure 9) (Kominz et al., 2008) and the Ypresian fluctuations in the West Siberian Sea (Radionova et al., 2003) have not (yet) been identified in the Tarim Basin. The following ca. 53-52 Ma regression fits with the Siberian Sea retreat but does not match the long-term global sea level reconstructions indicating a maximum sea level high (black dashed lines in Figure 9). We therefore speculate tectonic effects were likely more important driver for this retreat in the Tarim which is further corroborated by coeval uplift observed in subsidence curves (Figure 10). Unfortunately, major tectonic activity in this particular area and time period remains insufficiently constrained to couple specific tectonic activity to this regression. The timing of the regression may have roughly coincided with the initial early Eocene Indo-Asia collision and it has been previously speculated that its far-field deformation may have propagated to the northern part of the proto-Tibetan plateau at this time (Clark et al., 2010; Dayem et al., 2009; Jin et al., 2018; Jolivet et al., 2001, 2013) despite the ca. 3,000 km of separation (Dupont-Nivet et al., 2010). We conclude that this relatively small regression might have been tectonically driven but does not represent a major tectonic event in the area based on the small decrease in associated subsidence.

\subsection{3 | 2nd sea incursion (ca. 47-46 Ma to ca. 41-40 Ma)}

The 2nd Paleogene sea incursion in the Tarim Basin appears also coeval with the fluctuations in the Siberian Sea where a transgression during the Lutetian (starting at ca. $47 \mathrm{Ma}$ ) 

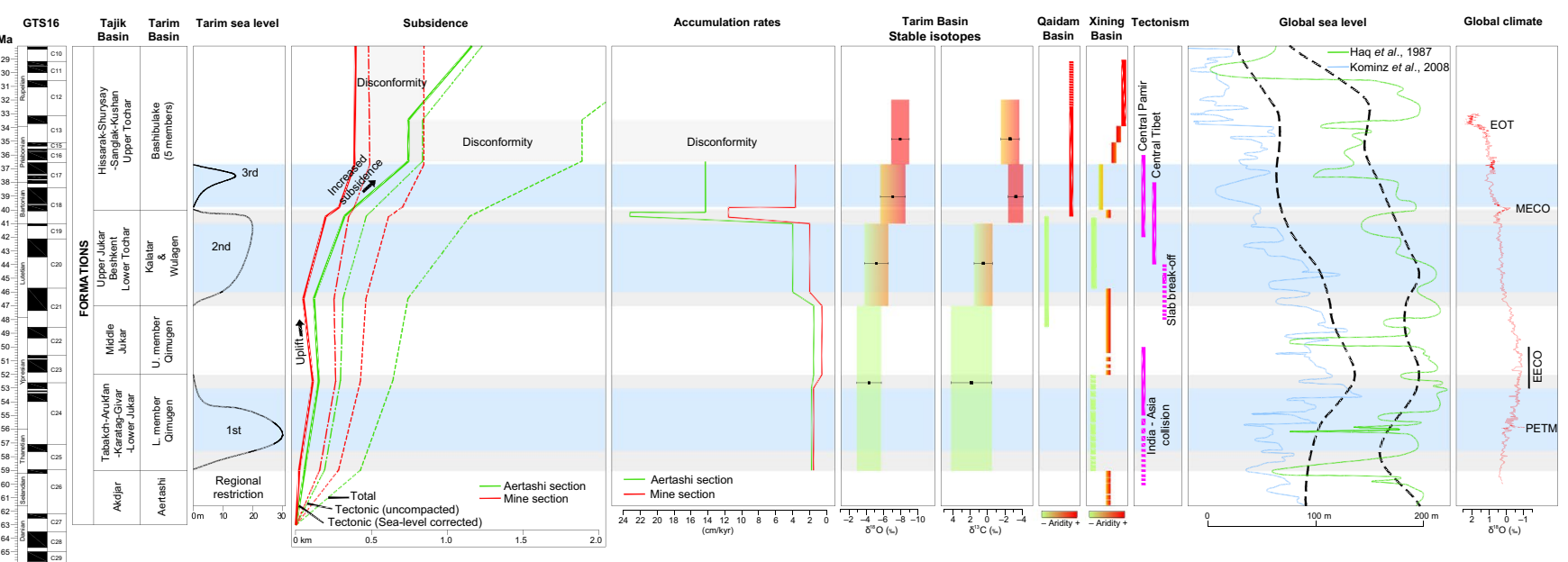

F I G U RE 10 Simplified regional lithostratigraphic framework of the Paleogene sea incursions in the Tarim and Tajik basins, compared temporally with the regional tectonic events and related magmatism (Chapman et al., 2018 and references therein; slab break-off data from Negredo et al., 2007), palaeoenvironmental changes recorded in the Qaidam (Bao et al., 2017; Song et al., 2013; Ye et al., 2016) and Xining (Abels et al., 2011; Hoorn et al., 2012; Meijer et al., 2018) basins, global sea level curve (Kominz et al., 2018 and Haq et al., 1987) and global climate events (benthic $\delta^{18} \mathrm{O}$ record of Cramer et al., 2009). The approximate relative changes in sea level in the Tarim Basin are shown by thick solid lines. The blue shaded areas highlight the sea incursions, which have been accurately dated in this study. Grey shaded parts indicate possible age interval for the onsets of transgressions and regressions. The subsidence curves for the Mine and Aertashi sections were produced by performing backstripping analysis using BasinVis 1.0 (Lee et al., 2016). Stable isotopic composition data for the Tarim Basin is from Bougeois et al. (2018)

is reported by Radionova et al. (2003) (Figure 12). During this interval, an increase is indicated in the global sea level reconstruction curve of Haq et al. (1987). Together, these suggest an eustatic control on the long-term trend of the 2nd Paleogene sea incursion in the Tarim Basin and West Siberian Sea.

For the following regression, the subsidence curves indicate an increase in tectonic subsidence at the initial deposition of the Kalatar Formation after a brief uplift event starting with the upper member of the Qimugen Formation deposition, discussed above (Figure 10). The regression seems at odds with increased subsidence. However, the regressive interval also corresponds to a prominent increase in accumulation rates between 41 and $40 \mathrm{Ma}$ suggesting a normal regression driven by excess sediment supply (Figures 10 and 11b). A net sea-level fall during this interval, also recorded in the West Siberian Sea and long-term eustatic curve (Figures 10 and 12), must have also induced an additional but less prominent component of forced regression. We therefore interpret the 2nd Paleogene regression to have been controlled by a combination of normal regression driven by excess sediment supply related to tectonism and a forced regression related to a net eustatic sea-level fall during this interval. In detail, we identify here that the onset of the increasing tectonic subsidence corresponds to sequence boundary 2 (SB2) in the marine deposits of the Kalatar Formation considering the increase in depositional thicknesses and accumulation rates thereafter (Figures 9 and Figure S5). Based on the presented age constraints on SB2, the onset of this increase in tectonic subsidence occurred within ca. 47 and ca. $41 \mathrm{Ma}$
(Figure 9 and 11a). The strong increase in tectonic subsidence is associated with a short interval of very fast accumulation rates of continental clastic sediment from ca. 41 to ca. $40 \mathrm{Ma}$. This ca. 41-40 Ma event is interpreted to relate to fast infilling of the previously under-filled marine basin. It is followed by more steady deposition in a continental foreland basin setting increasing up to the Miocene (Blayney et al., in revision) (Figure 11b). This marked tectonic phase coincides with the onset of regional deformation reported at similar ages further south in the Kunlun and Qiangtang as well as Northern and Central Pamir terranes (e.g. Wang et al., 2008; Amindon \& Hynek, 2010; Bershaw et al., 2012; Rutte et al., 2017). This regional event has been related to Pamir and Tibetan Plateau uplift, regional magmatism initiating around 44-42 Ma (Chapman et al., 2018 and references therein) and more generally to the effects of 'hard collision' following the Neo-Tethyan slab break-off or flattening ca. 45-40 Ma (DeCelles et al., 2011; Negredo et al., 2007; Replumaz et al., 2010; Smit et al., 2014; van Hinsbergen et al., 2018).

\subsection{4 | 3rd sea incursion (ca. 39.7-36.7 Ma)}

Our subsidence curve indicates the 3rd marine incursion occurs during increased tectonic subsidence directly after the ca. 41-40 Ma short infilling event described above (Figure 10). The 3rd incursion occurred in the Tajik Basin and the northwestern Tarim Basin from ca. 39.7 to 36.7 Ma but did not reach south Tarim where basin infilling was particularly strong (Figures 10 and 11c). The 3rd Paleogene sea incursion does not correspond in timing with the last Siberian 
S

(a) Onset of tectonics $\sim 47 \& 41 \mathrm{Ma}$

$\mathrm{N}$
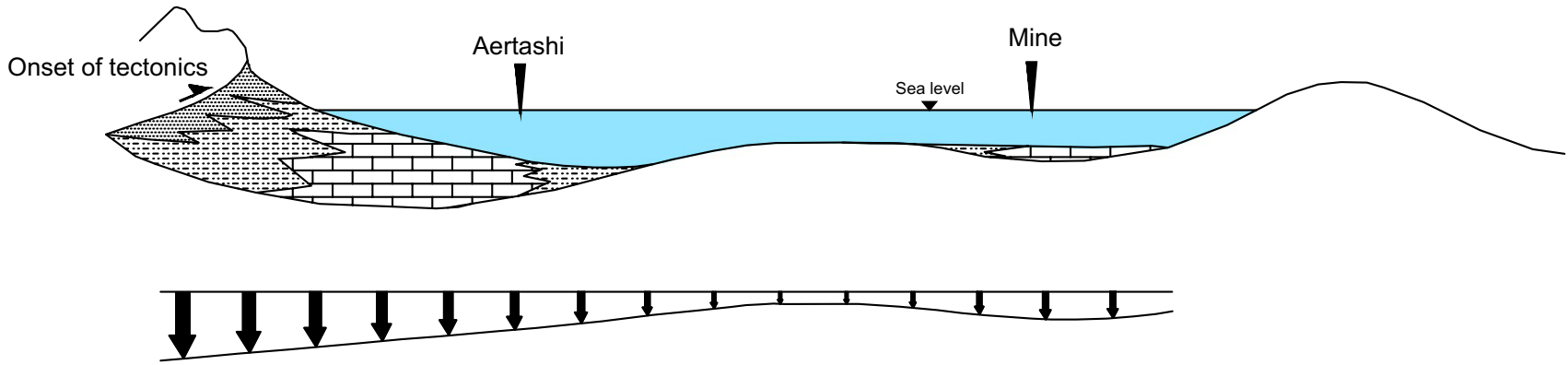

S

(b) 2nd regression $\sim 41-40 \mathrm{Ma}$

N
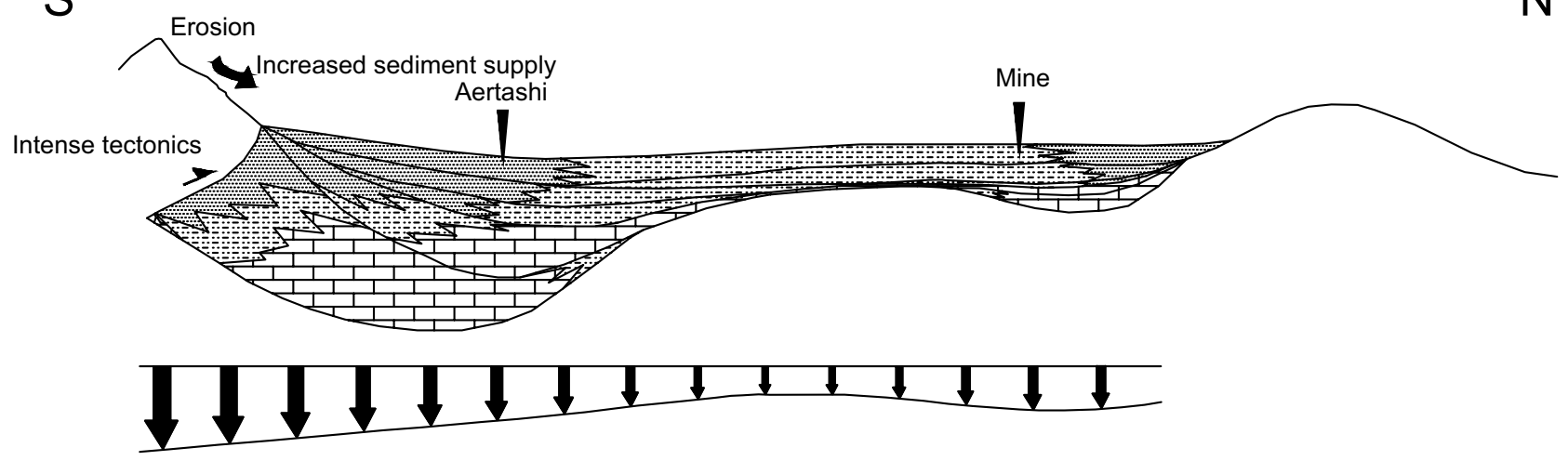

$\mathrm{S}$

(c) 3rd transgression $\sim 39 \mathrm{Ma}$
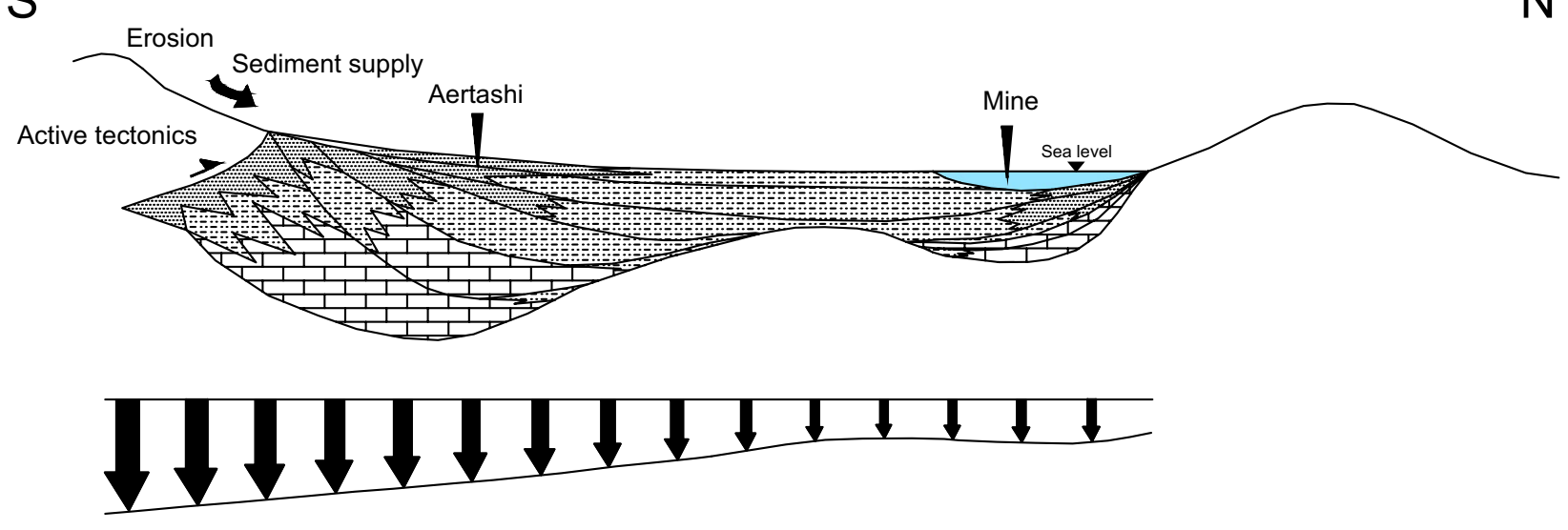

(d) 3rd regression $\sim 37-34 \mathrm{Ma}$

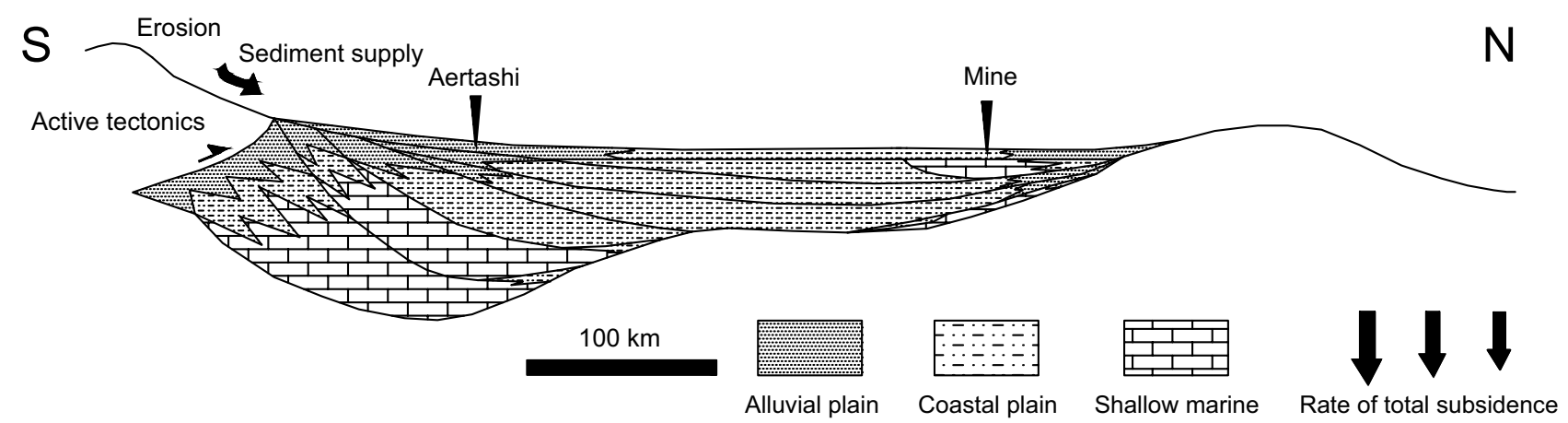


F I G U RE 11 Model showing total subsidence and stratigraphic fill of the Tarim Basin associated with the tectonic activity intensifying at ca. 41 Ma. This model refers to the foreland model of Catuneanu (2006). (a) Onset of the tectonic activity between ca. 47-41 Ma. Subsidence due to mainly tectonic loading and dynamic subsidence. (b) Intensification of the tectonic activity at ca. 41-40 Ma and the related increase in sediment supply and aggradation outpacing accommodation and resulting in the 2 nd regression throughout the basin. Subsidence due to tectonic loading, sediment loading and dynamic (c) Total subsidence outpaces the sediment infilling that has decreased in the north Tarim causing the 3rd transgression. In the south however, the infilling still outpaces accommodation, therefore no sea incursion occurs. Subsidence due to tectonic loading, sediment loading and dynamic subsidence. (d) The last regression is explained by northward propagation of aggradation outpacing subsidence

Sea incursion (Akhmetiev et al., 2012, 2010) or the early Priabonian eustatic fluctuations (Bosboom et al., 2014b; Haq et al., 1987; Kominz et al., 2008) (Figure 10). These together suggest that the 3rd Paleogene sea incursion was not primarily driven by eustasy. It is thus interpreted to relate to tectonic subsidence creating accommodation space overcoming basin infilling in the Tajik and northern Tarim basins after the initial ca. 41 to $40 \mathrm{Ma}$ excess sediment supply (Figure 11c). The following ca. 36.7 Ma regression is not expressed in the Siberian Sea records and does not correspond to a clear eustatic drop (Figure 10) although it is apparently synchronous from the northern Tarim Basin to the Tajik Basin. We thus rather interpret this regression to result from the ongoing tectonism and related to increased aggradational basin infilling prograding from the southern to northern Tarim Basin and into the Tajik Basin (Figure 11d).

We note that after the 3rd sea regression, marine facies are not recorded in the Tajik and Tarim basins that have higher accumulation rates of continental clastics and typical features of foreland basin deposits with little expression of eustasy (Figure 12). However, a long disconformity well dated from ca. 35.6 to ca. $33.3 \mathrm{Ma}$ in south Tarim at the Aertashi section, correlates well with the Siberian Sea regression occurring at ca. 34 Ma (Akhmetiev et al., 2012, 2010) and has been previously interpreted to relate to the ca. $100 \mathrm{~m}$ sea level drop at the Eocene-Oligocene transition (Bosboom et al., 2014a). This indicates that although tectonism was the major driving factor of long-term and possibly short-term fluctuations since ca. $41 \mathrm{Ma}$, the basins preserved an oceanic connection allowing for some eustatic influence.

\section{2 $\quad$ Effects on regional palaeoclimate}

Recent studies have established that the westerlies constitute a major moisture source to Central Asia and played a significant role in the aridification of the area since the Eocene (Bougeois, 2014; Bougeois et al., 2018; Caves et al., 2015). The long-term westward retreat of the Proto-Paratethys Sea during the Paleogene (starting ca. 52-53 Ma and ending ca. $36.7 \mathrm{Ma}$ ) likely removed a potentially significant moisture source to Central Asia (Bosboom et al., 2014a; Bougeois, 2014; Bougeois et al., 2018; Graham et al., 2005; Kent-Corson et al., 2009; Ramstein et al., 1997; Zhang et al., 2012) and therefore could have had a profound effect on progressive aridification in Central Asia. At shorter time scales, Paleogene sea transgressions and regressions may have modulated moisture supply provided by the westerlies to Central and East Asia. To test this, we compared our results constraining the evolution of the proto-Paratethys Sea to the long-term and short-term humid and arid phases existing in the palaeoenvironmental records further east in the Tarim Basin (this study), Qaidam Basin (Bao et al., 2017; Song et al., 2013; Ye et al., 2016) and the Xining Basin (Meijer et al., 2018).

In the Tarim Basin, well-dated continental palaeoenvironmental records from the Paleogene are rare and usually poorly constrained in age but suggest a long-term Paleogene to Neogene aridification (Wang et al., 1990; Wang et al., 2013). The pollen assemblages reported here confirm this long-term aridification now dated from Palaeocene to Eocene. Similarly, the late Palaeocene to late Eocene decrease in marine $\delta^{13} \mathrm{C}$ and $\delta^{18} \mathrm{O}$ values is also likely related to the long-term sea retreat and increasing effects of runoff by Bougeois et al. (2018) (Figure 10). The resolution of those datasets, however, does not allow for deciphering the shorterterm effects of the sea fluctuations.

In the Qaidam Basin, the timing of reported warmer and more humid climate conditions between ca. $48 \mathrm{Ma}$ and $40 \mathrm{Ma}$ (Bao et al., 2017; Song et al., 2013) is coeval with the 2nd Paleogene sea incursion (ca. 47-40 Ma) in the Tarim Basin (Figure 10). An aridification and cooling event has been proposed at ca. $40 \mathrm{Ma}$ (Song et al., 2013; Ye et al., 2016) that may be linked to the 2nd Proto-Paratethys Sea regression (ca. 41-40 Ma) and the related reduction of moisture transport from the sea eastward into Asia. Note, however, that age constraints on the Qaidam stratigraphy are controversial and may have to be radically limited to Neogene times (Wang et al., 2017).

In the Xining Basin further east, deposition of the late Palaeocene-early Eocene thick carbonaceous gypsum may coincide with the transgression of the 1st Paleogene sea incursion (ca. 59-57 Ma) in the SW Tarim Basin (Meijer et al., 2018). The subsequent sudden increase in lacustrine deposits at ca. 45.7 Ma is closely linked with the transgression of the 2nd Paleogene sea incursion (Bosboom et al., 2014a; Meijer et al., 2018). An aridification step at ca. 41-40 Ma is then indicated by regional disappearance of this perennial lake system and shift to a more arid flora (Bosboom et al., 

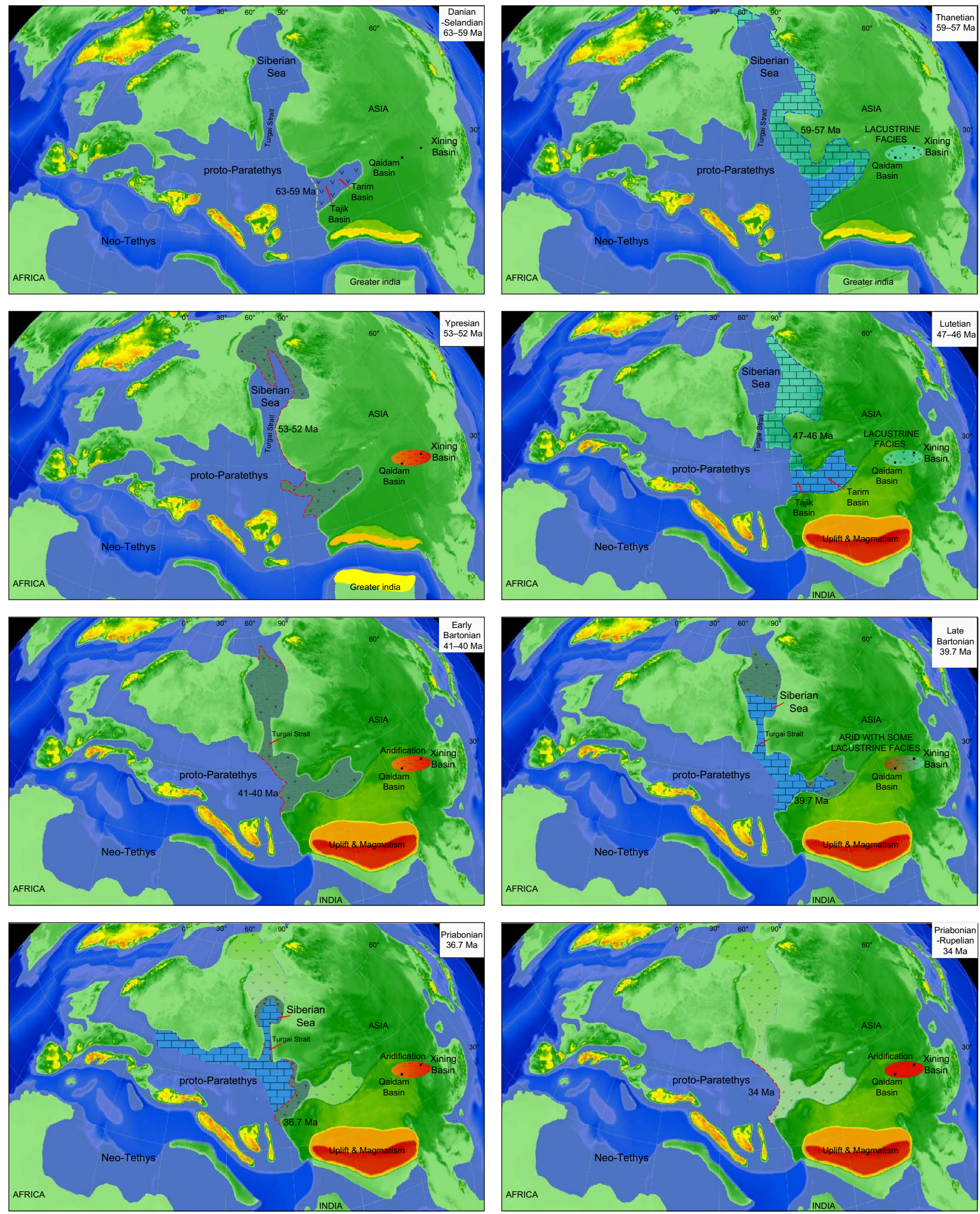

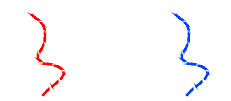

Max. regression transgression

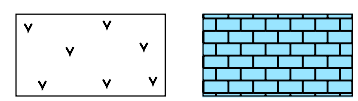

Shelf evaporites Shallow marine

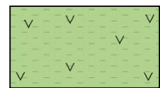

Coastal marine (transitional)

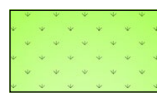

Continental

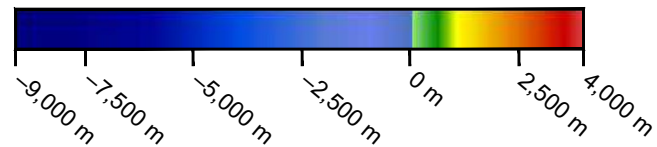


F I G U RE 12 Palaeogeographic maps displaying the early Paleogene regional restriction event and sea incursions. Numerical ages in the figures show the onset of individual transgressions and regressions whereas the palaeogeographies show the maximum transgressions and regressions. Coastline for the 3rd regression is based on Bosboom et al. (2017). All other coastlines during the Paleogene sea incursions were drawn based on the results of this study and Peri-Tethys atlas (Dercourt et al., 2000). Palaeogeographical changes in the Turgai Strait and Siberian Sea were drawn based on Radionova et al. (2003), Akhmetiev and Beniamovski (2009), Akhmetiev et al. (2012, 2010), and our new results. Corresponding facies during the transgressions and regressions can also be seen on the palaeogeographic maps. Note also that transgressions and regressions are coeval with the humid and arid phases reported from the Xining and Qaidam basins

2014c). This has been previously linked to the regression of the 2nd Paleogene sea incursion by Bosboom et al. (2014a) (Figure 10). Finally, the last sea incursion in the Tarim Basin now dated in this study as ca. 39.7-36.7 Ma (C17n.1n) corresponds to the more gypsiferous interval before the aridification step 1 and the appearance of Picea associated with a drastic environmental change (Abels et al, 2011; Hoorn et al., 2012). This suggests that this interval was relatively humid due to the sea incursion and followed by aridification and possibly cooling at ca. $36.7 \mathrm{Ma}$ corresponding to the Picea appearance in the Xining Basin (Figure 10).

Tectonic control on the long-term aridification of the basins north of the growing Tibetan Plateau is well established (Graham et al., 2005). However, shorter-term changes of wet/arid depositional systems are unlikely related to the influence of local tectonics (in particular uplift) but rather represent fluctuations in atmospheric moisture (Abels et al., 2011; Dupont-Nivet et al., 2007; Meijer et al., 2018). Indeed, episodic local tectonic events would require associated variations in depositional environments with fluctuations in accumulation rates and coarsening trends that are not observed. In the Paleogene, the Qaidam and Xining basins record slow and constant sediment accumulation before the dominantly Neogene exhumation of local mountain ranges (Ji et al., 2017; Meijer et al., 2018). The short-term change of depositional systems representing moisture shifts in the Qaidam and Xining Basin also do not correspond with global climate events (e.g. Meijer et al., 2018). Therefore, these findings of moisture fluctuations in the Xining and Qaidam basins coeval with sea transgressions and regressions in the Tarim Basin strengthen the hypothesis that the proto-Paratethys Sea was an important mechanism influencing the westerly flux of moisture into Asia during the Paleogene.

\section{6 | CONCLUSIONS}

Our new regional stratigraphic framework provides solid age constraints for the early Paleogene sea incursions in the SW Tarim and Tajik basins. Based on our results, a major regional restriction event represented by the thick and extensive gypsum deposits occurred between ca. $63 \mathrm{Ma}$ and ca. 59-57 Ma (Danian to possibly Selandian). This was followed by the 1st transgression event around 59-57 Ma (base of Thanetian), possibly driven by eustasy, resulting in the maximum geographic extent and deepest offshore marine environment of the proto-Paratethys. The 1st Paleogene regression occurred around 53-52 Ma (Ypresian; C24n.1r-C23r) and was likely caused by far-field tectonic effects, possibly due to the coeval early Eocene Indo-Asia collision deformation. The age of the 2nd Paleogene transgression, represented by the establishment of a carbonate ramp system, is determined as ca. 47-46 Ma (C21n) and, similar to the first transgression, may be related to eustatic fluctuations. The subsequent regression starting at ca. $41 \mathrm{Ma}$ and followed by a dramatic increase in tectonic subsidence can be related to regional tectonic events reported in the Pamir and Tibetan Plateau around 45-40 Ma. The last sea transgression event driven by the combined effects of increased tectonic subsidence and decreased accumulation rates occurred at ca. 39.7 Ma (within C18n.2n). The following westward final retreat of the proto-Paratethys Sea (at ca. $36.7 \mathrm{Ma}$ ) is thus interpreted as being caused by increased basin infilling associated with the Pamir/Tibetan tectonic activity. These interpretations for the Paleogene sea incursions support the assessment that far-field tectonic effects of India-Asia collision and early Pamir/Tibetan activation intensifying at ca. $41 \mathrm{Ma}$ forced the long-term westward retreat of the proto-Paratethys Sea by driving the Paleogene regressions. Although tectonism was the primary driver since ca. $41 \mathrm{Ma}$, short-term as well as long-term sea level fluctuations may have contributed as well. Palynofloral assemblages indicate semi-arid and temperate environments in the late Palaeocene and early Eocene, which then warmed in the middle Eocene and became drier in the late Eocene. The transgressive/regressive intervals of the proto-Paratethys Sea in the SW Tarim Basin coincide with the less arid/more arid phases in the Qaidam and Xining basins, establishing the proto-Paratethys as a major important moisture source for the Asian interior and demonstrating its importance as a contributor to Asian aridification.

\section{ACKNOWLEDGEMENTS}

This project was funded by ERC consolidator grant MAGIC 649081. We thank Cécile Robin, Fernando Poblete and Ed Sobel for fruitful advice and discussions. JF thanks Arjen Grothe, Margot Cramwinckel and Appy Sluijs for helpful discussions on dinocyst biostratigraphy. We also thank the editor and two anonymous reviewers for their constructive and insightful comments. 


\section{ORCID}

\section{Mustafa Y. Kaya (D) https://orcid.org/0000-0003-2966-5092}

\section{REFERENCES}

Abels, H. A., Dupont-Nivet, G., Xiao, G., Bosboom, R., \& Krijgsman, W. (2011). Step-wise change of Asian interior climate preceding the Eocene-Oligocene Transition (EOT). Palaeogeography, Palaeoclimatology, Palaeoecology, 299(3-4), 399-412. https://doi. org/10.1016/j.palaeo.2010.11.028

Agnini, C., Fornaciari, E., Raffi, I., Catanzariti, R., Pälike, H., Backman, J., \& Rio, D. (2014). Biozonation and biochronology of Paleogene calcareous nannofossils from low and middle latitudes. Newsletters on Stratigraphy, 47(2), 131-181. https://doi. org/10.1127/0078-0421/2014/0042

Akhmetiev, M. A., \& Beniamovski, V. N. (2009). Paleogene floral assemblages around epicontinental seas and straits in Northern Central Eurasia: Proxies for climatic and paleogeographic evolution. Geologica Acta, 7, 297-309.

Akhmetiev, M. A., Zaporozhets, N. I., Benyamovskiy, V. N., Aleksandrova, G. N., Iakovleva, A. I., \& Oreshkina, T. V. (2012). The Paleogene history of the western Siberian seaway - A connection of the Peri-Tethys to the Arctic Ocean. Austrian Journal of Earth Sciences, 105, 50-67.

Akhmetiev, M. A., Zaporozhets, N. I., Iakovleva, A. I., Aleksandrova, G. N., Benyamovskiy, V. N., Oreshkina, T. V., ... Dolya, Z. A. (2010). Comparative analysis of marine Paleogene sections and biota from west Siberia and the Arctic Region. Stratigraphy and Geological Correlation, 18, 635-659. https://doi.org/10.1134/ S0869593810060043

Amidon, W. H., \& Hynek, S. A. (2010). Exhumational history of the north central Pamir. Tectonics, 29, TC5017. https://doi. org/10.1029/2009TC002589

Bao, J., Wang, Y., Song, C., Feng, Y., Hu, C., Zhong, S., \& Yang, J. (2017). Cenozoic sediment flux in the Qaidam Basin, northern Tibetan Plateau, and implications with regional tectonics and climate. Global and Planetary Change, 155, 56-69. https://doi. org/10.1016/j.gloplacha.2017.03.006

Barrier, E., Vrielynck, B., Brouillet, J. F., \& Brunet, M. F. (Contributors : Angiolini L., Kaveh F., Poisson A., Pourteau A., Plunder A., Robertson A., Shekawat R., Sosson M. and Zanchi A.) (2018). Paleotectonic Reconstruction of the Central Tethyan Realm. Tectonono-Sedimentary-Palinspastic maps from Late Permian to Pliocene. CCGM/CGMW, Paris, http://www.ccgm.org. Atlas of 20 maps (scale: $1 / 15000000)$

Berggren, W. A., \& Aubert, J. (1975). Paleocene benthonic foraminiferal biostratigraphy, paleobiogeography and paleoecology of Atlantic-Tethyan regions: Midway-type fauna. Palaeogeography, Palaeoclimatology, Palaeoecology, 18(2), 73-192. https://doi. org/10.1016/0031-0182(75)90025-5

Bershaw, J., Garzione, C. N., Schoenbohm, L., Gehrels, G., \& Tao, L. (2012). Cenozoic evolution of the Pamir Plateau based on stratigraphy, zircon provenance, and stable isotopes of foreland basin sediments at Oytag (Wuyitake) in the Tarim Basin (West China). $J$. Asian Earth Sci., 44, 136-148.

Bijl, P. K., Brinkhuis, H., Egger, L. M., Eldrett, J. S., Frieling, J., Grothe, A., ... Sluijs, A.. (2016). Comment on "Wetzeliella and its allies - the 'hole' story: a taxonomic revision of the Paleogene dinoflagellate subfamily Wetzelielloideae" by Williams et al. (2015). Palynology, 6122, 1-7. https://doi.org/10.1080/0191612 2.2016.1235056

Bijl, P. K., Sluijs, A., \& Brinkhuis, H. (2013). A magneto- and chemostratigraphically calibrated dinoflagellate cyst zonation of the early Paleogene South Pacific Ocean. Earth Science Reviews, 124, 1-31.

Blayney, T., Dupont-Nivet, G., Najman, Y., Proust, J., Meijer, N., Roperch, P., ...Guo, Z.. (in revision). Pamir tectonic evolution recorded in the western Tarim Basin (China): sedimentologic and magnetostratigraphic analyses of the Aertashi section. Tectonics

Blayney, T., Najman, Y., Dupont-Nivet, G., Carter, A., Millar, I., Garzanti, E., ... Vezzoli, G. (2016). Indentation of the Pamirs with respect to the northern margin of Tibet: Constraints from the Tarim basin sedimentary record. Tectonics, 35(10), 2345-2369. https://doi. org/10.1002/2016TC004222

Blum, M. D., \& Törnqvist, T. E. (2000). Fluvial responses to climate and sea-levelchange: Areview and lookforward.Sedimentology,47(Suppl. 1), 2-48. https://doi.org/10.1046/j.1365-3091.2000.00008.x

Bosboom, R., Ables, H. A., Hoorn, C., van den Berg, B. C. J., Guo, Z., \& Dupont-Nivet, G. (2014c). Aridification in continental Asia after the Middle Eocene Climatic Optimum (MECO). Earth and Planetary Science Letters, 389, 34-42.

Bosboom, R., Mandic, O., Dupont-Nivet, G., Proust, J.-N., Ormukov, C., \& Aminov, J. (2017). Late Eocene palaeogeography of the proto-paratethys Sea in Central Asia (NW China, southern Kyrgyzstan and SW Tajikistan). Geological Society, London, Special Publications, 427(1), 565-588. https://doi.org/10.1144/SP427.11

Bosboom, R., Dupont-Nivet, G., Grothe, A., Brinkhuis, H., Villa, G., Mandic, O., ... Krijgsman, W. (2014a). Linking Tarim Basin sea retreat (west China) and Asian aridification in the late Eocene. Basin Research, 26(5), 621-640. https://doi.org/10.1111/bre.12054

Bosboom, R., Dupont-Nivet, G., Grothe, A., Brinkhuis, H., Villa, G., Mandic, O., ... Guo, Z. J. (2014b). Timing, cause and impact of the late Eocene stepwise sea retreat from the Tarim Basin (west China). Palaeogeography, Palaeoclimatology, Palaeoecology, 403, 101-118. https://doi.org/10.1016/j.palaeo.2014.03.035

Bosboom, R. E., Dupont-Nivet, G., Houben, A. J. P., Brinkhuis, H., Villa, G., Mandic, O., ... Krijgsman, W. (2011). Late Eocene sea retreat from the Tarim Basin (west China) and concomitant Asian paleoenvironmental change. Palaeogeography, Palaeoclimatology, Palaeoecology, 299(3-4), 385-398. https://doi.org/10.1016/j.palaeo.2010.11.019

Bougeois, L. (2014). Paleogene seasonal variability in Central Asia: Constrains from high-resolution geochemistry on oyster shells. University of Rennes. PhD dissertation.

Bougeois, L., Dupont-Nivet, G., de Rafélis, M., Tindall, J. C., Proust, J.-N., Reichart, G.-J., ... Ormukov, C. (2018). Asian monsoons and aridification response to Paleogene sea retreat and Neogene westerly shielding indicated by seasonality in Paratethys oysters. Earth and Planetary Science Letters, 485, 99-110. https://doi.org/10.1016/j. eps1.2017.12.036

Bown, P. R. (2005). Paleogene calcareous nannofossils from the Kilwa and Lindi areas of coastal Tanzania (Tanzania Drilling Project 2003-4). Journal of Nannoplankton Research, 27, 21-95.

Bown, P. R., \& Young, J. R. (1998). Techniques. In P. R. Bown (Ed.), Calcareous nannofossil biostratigraphy (pp. 16-28). Cambridge, UK: Chapman \& Hall.

Burchette, T. P., \& Wright, V. P. (1992). Carbonate ramp depositional systems. Sedimentary Geology, 79(1-4), 3-57. https://doi. org/10.1016/0037-0738(92)90003-A 
Burtman, V. S. (2000). Cenozoic crustal shortening between the Pamir and Tien Shan and a reconstruction of the Pamir-Tien Shan transition zone for the Cretaceous and Paleogene. Tectonophysics, 319(2), 69-92. https://doi.org/10.1016/S0040-1951(00)00022-6

Burtman, V. S., \& Molnar, P. H. (1993). Geological and geophysical evidence for deep subduction of continental crust beneath the pamir. Boulder, Colorado, Geological Society of America Special Papers, 281.

Cao, K., Wang, G. C., Bernet, M., van der Beek, P., \& Zhang, K. X. (2015). Exhumation history of the West Kunlun Mountains, northwestern Tibet: Evidence for a long-lived, rejuvenated orogen. Earth and Planetary Science Letters, 432, 391-403. https://doi. org/10.1016/j.eps1.2015.10.033

Catuneanu, O. (2006). Principles of sequence stratigraphy. Elsevier, Amsterdam. 375 pp.

Caves, J. K., Winnick, M. J., Graham, S. A., Sjostrom, D. J., Mulch, A., \& Chamberlain, C. P. (2015). Role of the westerlies in Central Asia climate over the Cenozoic. Earth and Planetary Science Letters, 428, 33-43. https://doi.org/10.1016/j.eps1.2015.07.023

Chapman, J. B., Scoggin, S. H., Kapp, P., Carrapa, B., Ducea, M. N., Worthington, J., ... Gadoev, M. (2018). Mesozoic to Cenozoic magmatic history of the Pamir. Earth and Planetary Science Letters, 482, 181-192. https://doi.org/10.1016/j.eps1.2017.10.041

Chinese Bureau of Stratigraphy (1981). Stratigraphic tables for Xinjiang Autonomous Region, $496 \mathrm{p}$.

Clark, M. K., Farley, K. A., Zheng, D., Wang, Z., \& Duvall, A. R. (2010). Early Cenozoic faulting of the northern Tibetan Plateau margin from apatite (U-Th)/He ages. Earth and Planetary Science Letters, 296(1-2), 78-88. https://doi.org/10.1016/j.epsl.2010.04.051

Cowgill, E. (2010). Cenozoic right-slip faulting along the eastern margin of the Pamir salient, northwestern China. Bulletin of the Geological Society of America, 122(1-2), 145-161. https://doi.org/10.1130/B26520.1

Cramer, B. S., Toggweiler, J. R., Wright, J. D., Katz, M. E., \& Miller, K. G. (2009). Ocean overturning since the Late Cretaceous: Inferences from a new foraminiferal isotope compilation. Paleoceanography, 24, PA4216. https://doi.org/10.1029/2008PA001683

Crouch, E. M., Heilmann-Clausen, C., Brinkhuis, H., Morgans, H. E. G., Rogers, K. M., Egger, H., \& Schmitz, B. (2001). Global dinoflagellate event associated with the late Paleocene thermal maximum. Geology, 29, 315-318. https://doi. org/10.1130/0091-7613(2001)029<0315:GDEAWT > 2.0.CO;2

Cushman, J. A. (1951). Paleocene foraminifera of the Gulf coastal region of the United States and adjacent areas. U.S. Geological Survey Professional Paper, 232, 75.

Dayem, K. E., Molnar, P., Clark, M. K., \& Houseman, G. A. (2009). Farfield lithospheric deformation in Tibet during continental collision. Tectonics, 28(6), TC6005.

DeCelles, P. G., Kapp, P., Quade, J., \& Gehrels, G. E. (2011). OligoceneMiocene Kailas basin, southwestern Tibet: Record of postcollisional upper-plate extension in the Indus-Yarlung suture zone. Bulletin of the Geological Society of America, 123(7-8), 1337-1362. https:// doi.org/10.1130/B30258.1

Dercourt, J., Gaetani, M., Vrielynck, B., Barrier, E., Biju-Duval, B., Brunet, M. F., Sandulescu, M.. (2000). Peri-Tethys paleogeographical atlas.

Dupont-Nivet, G., Krijgsman, W., Langereis, C. G., Abels, H. A., Dai, S., \& Fang, X. (2007). Tibetan plateau aridification linked to global cooling at the Eocene-Oligocene transition. Nature, 445(7128), 635-638. https://doi.org/10.1038/nature05516
Dupont-Nivet, G., Lippert, P. C., vanHinsbergen, J. J. D., Meijers, M., \& Kapp, P. (2010). Palaeolatitude and age of the Indo-Asia collision: Palaeomagnetic constraints. Geophysical Journal International, 182, 1189-1198. https://doi.org/10.1111/j.1365-246X.2010. 04697.x

Eldrett, J. S., Harding, I. C., Firth, J. V., \& Roberts, A. P. (2004). Magnetostratigraphic calibration of Eocene-Oligocene dinoflagellate cyst biostratigraphy from the Norwegian-Greenland Sea. Marine Geology, 204, 91-127. https://doi.org/10.1016/ S0025-3227(03)00357-8

Fensome, R. A., \& Williams, G. L. (2004). The Lentin and Williams Index of Fossil Dinoflagellates 2004 Edition, 909 pp. Am. Assoc.of Strat. Coll. Station. Tex.

Fisher, R. A. (1953). Dispersion on a sphere. Proc. R. Soc. Lond. A, 217(1130), 295-305.

Flügel, E. (2004). Microfacies of carbonate rocks: Analysis, interpretation and application. Berlin: Springer.

Fornaciari, E., Agnini, C., Catanzariti, R., Rio, D., Bolla, E. M., \& Valvasoni, E. (2010). Mid-latitude calcareous nannofossil biostratigraphy, biochronology and evolution across the middle to late Eocene transition. Stratigraphy, 7, 229-264.

Graham, S. A., Chamberlain, C. P., Yue, Y., Ritts, B. D., Hanson, A. D., Horton, T. W., ... Feng, X. (2005). Stable isotope records of cenozoic climate and topography, Tibetan plateau and Tarim basin. American Journal of Science, 305(2), 101-118. https://doi. org/10.2475/ajs.305.2.101

Guasti, E., \& Speijer, R. P. (2008). Acarinina multicamerata n. sp. (Foraminifera): A new marker for the Paleocene-Eocene thermal maximum. Journal of Micropalaeontology, 27, 5-12.

Guo, F., Yang, D., Eriksson, K. A., \& Guo, L. (2015). Paleoenvironments, stratigraphic evolution and reservoir characteristics of the Upper Cretaceous Yingjisha Group, southwest Tarim Basin. Marine and Petroleum Geology, 67, 336-355. https://doi.org/10.1016/j. marpetgeo.2015.05.023

Guo, X. (1990). Study on marine Cretaceous-Tertiary boundary in the western Tarim Basin. Journal of China University of Geosciences, 15, 325-335.

Guo, Z. T., Sun, B., Zhang, Z. S., Peng, S. Z., Xiao, G. Q., Ge, J. Y., ... Wei, J. J. (2008). A major reorganization of Asian climate by the early Miocene. Climate of the past, 4, 153-174.

Hao, Y., \& Guo, X. (1990). Cretaceous-Paleocene foraminiferal communities from the western Tarim basin and their environmental significance. Journal of China University of Geosciences, 1, 34-42.

Hao, Y. C., Zeng, X. L., \& Li, H. M. (1982). Late Cretaceous and Tertiary strata and foraminifera in Western Tarim Basin. Earth Science-Journal of the Wuhan College of Geology, 17, 1-114. (In Chinese with English abstract).

Hao, Y. C., Guo, X. P., Ye, L. S., Yao, P. Y., Fu, D. R., Li, H. M., ... Wang, D. N. (2001). The boundary between the marine Cretaceous and Tertiary in the southwest Tarim Basin. Bejing: Geological Publishing House.

Haq, B. U., Hardenbol, J., \& Vail, P. R. (1987). Chronology of fluctuating sea levels since the Triassic (250 million years ago to present). Science, 235, 1156-1167. https://doi.org/10.1126/ science.235.4793.1156

Heermance, R. V., Chen, J., Burbank, D. W., \& Wang, C. S. (2007). Chronology and tectonic controls of Late Tertiary deposition in the southwestern Tian Shan foreland, NW China. Basin Research, 19, 599-632. http://dx.doi.org/10.1111/j.1365-2117.2007.00339.x 
Hendrix, M. S., Graham, S. A., Carroll, A. R., Sobel, E. R., McKnight, C. L., Schulein, B. J., \& Wang, Z. (1992). Sedimentary record and climatic implications of recurrent deformation in the Tian Shan: Evidence from Mesozoic strata of the north Tarim, south Junggar, and Turpan basins. Geological Society of America Bulletin, 104, 53-79.

Hoorn, C., Straathof, J., Abels, H. A., Xu, Y., Utescher, T., \& DupontNivet, G. (2012). A late Eocene palynological record of climate change and Tibetan Plateau uplift (Xining Basin, China). Palaeogeography, Palaeoclimatology, Palaeoecology, 344-345, 16-38. https://doi.org/10.1016/j.palaeo.2012.05.011

Hu, X., Garzanti, E., Wang, J., Huang, W., An, W., \& Webb, A. (2016). The timing of India-Asia collision onset - Facts, theories, controversies. Earth-Science Reviews, 160, 264-299. https://doi. org/10.1016/j.earscirev.2016.07.014

Hudson, J. D. (1977). Stable isotopes and limestone lithification. Journal of the Geological Society, 133, 637-660. https://doi.org/10.1144/ gsjgs.133.6.0637

Iakovleva, A. I., \& Heilmann-Clausen, C. (2007). Wilsonidium pechoricum new species-A new dinoflagellate species with unusual asymmetry from the Paleocene/Eocene transition. Journal of Paleontology, 81, 1020-1030.

James,N.P., \& Walker, R.G. (1992). Facies Models: response to sea level changes. Geological Association of Canada, 409 pp.

Ji, J., Zhang, K., Clift, P. D., Zhuang, G., Song, B., Ke, X., \& Xu, Y. (2017). High-resolution magnetostratigraphic study of the Paleogene-Neogene strata in the Northern Qaidam Basin: Implications for the growth of the Northeastern Tibetan Plateau. Gondwana Research, 46, 141-155. https://doi.org/10.1016/j. gr.2017.02.015

Jia, C. Z., Zhang, S. B., Wu, S. Z. (2004). Stratigraphy of the tarim basin and adjacent areas. Beijing: Sci. Press, $450 \mathrm{pp}$.

Jin, C., Liu, Q., Liang, W., Roberts, A. P., Sun, J., Hu, P., ... Yuan, S. (2018). Magnetostratigraphy of the Fenghuoshan Group in the Hoh Xil Basin and its tectonic implications for India-Eurasia collision and Tibetan Plateau deformation. Earth and Planetary Science Letters, 486, 41-53. https://doi.org/10.1016/j.epsl.2018.01.010.

Jolivet, M., Brunel, M., Seward, D., Xu, Z., Yang, J., Roger, F., ... Wu, C. (2001). Mesozoic and Cenozoic tectonics of the northern edge of the Tibetan plateau: Fission-track constraints. Tectonophysics, 343(12), 111-134. https://doi.org/10.1016/S0040-1951(01)00196-2.

Jolivet, M., Heilbronn, G., Robin, C., Barrier, L., Bourquin, S., Guo, Z., ... Fu, B. (2013). Reconstructing the Late Palaeozoic-Mesozoic topographic evolution of the Chinese Tian Shan: Available data and remaining uncertainties. Advances in Geosciences, 37, 7-18. https:// doi.org/10.5194/adgeo-37-7-2013

Kent-Corson, M. L., Ritts, B. D., Zhuang, G., Bovet, P. M., Graham, S. A., \& Page Chamberlain, C. (2009). Stable isotopic constraints on the tectonic, topographic, and climatic evolution of the northern margin of the Tibetan Plateau. Earth and Planetary Science Letters, 282(1-4), 158-166. https://doi.org/10.1016/j. eps1.2009.03.011

Kirschvink, J. L. (1980). The least-square line and plane and the analysis of paleomagnetic data. Geophysical Journal of the Royal Astronomical Society, 62, 699-718.

Kominz, M. A., Browning, J. V., Miller, K. G., Sugarman, P. J., \& Mizintseva, S. (2008). Late cretaceous to miocene sea-level estimates from the New Jersey and Delaware coastal plain coreholes: An error analysis. Basin Research, 20, 211-226. https://doi. org/10.1111/j.1365-2117.2008.00354.x
Köthe, A. (2012). A revised Cenozoic dionflagellate cyst and calcareous nannoplankton zonation for the German sector of the southeastern North Sea Basin. Newsletters on Stratigraphy, 45, 189-220.

Kutzbach, J. E., Prell, W. L., \& Ruddiman, W. F. (1993). Sensitivity of Eurasian climate to surface uplift of the Tibetan Palteau. The Journal of Geology, 101, 177-190.

Lan, X., \& Wei, J. (1995). Late Cretaceous-Early Tertiary Marine Bivalve Fauna From the Western Tarim Basin. Chinese Science Publishing House, Beijing p. 212.

Lee, E. Y., Novotny, J., \& Wagreich, M. (2016). BasinVis 1.0: A MATLAB $®$-based program for sedimentary basin subsidence analysis and visualization. Computers and Geosciences, 91, 119-127. https://doi.org/10.1016/j.cageo.2016.03.013

LeRoy, L. W. (1953). Biostratigraphy of the Maqfi section. Egypt. GSA, Mem., 54, 73 pp.

Li, X., Zhang, R., Zhang, Z., \& Yan, Q. (in press). What enhanced the aridity in Eocene Asian inland: Gglobal cooling or early Tibetan Plateau uplift? Palaeogeography, Palaeoclimatology, Palaeoecology. 510, 6-14. doi: 10.1016/j.palaeo.2017.10.029.

Li, Y. (1990). An Apparent Polar Wander Path from the Tarim Block, China. Tectonophysics, 181, 31-41. https://doi. org/10.1111/j.1755-6724.1990.mp3001001.x

Licht, A., Dupont-Nivet, G., Pullen, A., Kapp, P., Abels, H. A., Lai, Z., ... Giesler, D. (2016). Resilience of the Asian atmospheric circulation shown by Paleogene dust provenance. Nature Communications, 7, 12390. https://doi.org/10.1038/ncomms12390

Licht, A., van Cappelle, M., Abels, H. A., Ladant, J. B., TrabuchoAlexandre, J., France-Lanord, C., ... Jaeger, J. J. (2014). Asian monsoons in a late Eocene greenhouse world. Nature, 513(7519), 501506. 10.1038/nature13704ไrhttp://www.nature.com/nature/journal/ v513/n7519/abs/nature13704.html\#supplementary-information

Loeblich, A. R. J., \& Tappan, H. (1988). Foraminiferal genera and their classification (p. 970). New York, NJ: Van Nostrand Reinhold.

Lu, H., Wang, X., \& Li, L. (2010). Aeolian sediment evidence that global cooling has driven late Cenozoic stepwise aridification in central Asia. Geological Society London Special Publications, 342, 29-44. https://doi.org/10.1144/SP342.4

Manabe, S., \& Broccoli, A. J. (1990). Mountains and arid climates of Middle latitudes. Science, 247, 192-195. https://doi.org/10.1126/ science.247.4939.192

Mao, S., \& Norris, G. (1988). Late Cretaceous - Early Tertiary Dinoflagellates and Acritarchs from the Kashi Area, Tarim Basin, Xinjiang Province, China. Toronto, ON: Royal Ontario Museum Life Sciences Publications.

Martini, E. (1971). Standard Tertiary and Quaternary calcareous nannoplankton zonation. In A. Farinacci (Eds.), Proceedings 2nd International Conference Planktonic Microfossils Roma, 2, 739-785.

McFadden, P. L., \& McElhinny, M. W. (1988). The combined analysis of remagnetization circles and direct observations in palaeomagnetism. Earth and Planetary Science Letters, 87(1-2), 161-172. https://doi.org/10.1016/0012-821X(88)90072-6

Meijer, N., Dupont-Nivet, G., Abels, H., Kaya, M. Y. K., Licht, A., Xiao, M., ... Guo, Z. (2018). Central Asian moisture modulated by protoParatethys Sea incursions since the early Eocene. Manuscript submitted for publication to Earth Palnet. Sci. Lett.

Mudge, D. C., \& Bujak, J. P. (1996). Palaeocene biostratigraphy and sequence stratigraphy of the UK central North Sea. Marine and Petroleum Geology, 13, 295-312. https://doi. org/10.1016/0264-8172(95)00066-6 
Negredo, A. M., Replumaz, A., Villaseñor, A., \& Guillot, S. (2007). Modeling the evolution of continental subduction processes in the Pamir-Hindu Kush region. Earth and Planetary Science Letters, 259(1-2), 212-225. https://doi.org/10.1016/j.eps1.2007.04.043

Nelson, C. S., \& Smith, A. M. (1996). Stable oxygen and carbon isotope compositional fields for skeletal and diagenetic components in New Zealand Cenozoic nontropical carbonate sediments and limestones: A synthesis and review. New Zealand Journal of Geology and Geophysics, 39, 93-107. https://doi.org/10.1080/00288306.1996.9514697

Ogg, J. G., Ogg, G. M., \& Gradstein, F. M. (2016). A concise geological time scale (240 pp.). Amsterdam: Elsevier.

Okada, H. \& Bukry, D. (1980). Supplementary modification and introduction of code numbers to the low latitude coccolith biostratigraphic zonation. Marine Micropaleontology, 5, 321-325. https:// doi.org/10.1016/0377-8398(80)90016-X

Olsson, R. K., Hemleben, C., Berggren, W. A., \& Huber, B. T. (Eds.) (1999). Atlas of paleocene planktonic foraminifera. Smithsonian Contributions to Paleobiology, 85, 1-252.

Pearson, P. N., Olsson, R. K., Huber, B. T., Hemleben, C., \& Berggren, W. A.(eds.) (2006). The Atlas of Eocene Planktonic Foraminifera, Cushman Foundation Special Publication, 41. 514 pp.

Perch-Nielsen, K. (1985). Cenozoic calcareous nannofossils. In H. M. Bolli, J. B. Saunders, \& K. Perch-Nielsen (Eds.), Plankton Stratigraphy (pp. 427-554). Cambridge: Cambridge University Press.

Poblete, F., Dupont-Nivet, G., Licht, A., van Hinsbergen, D., Roperch, P., Guillocheau, F., ...Baatsten, M. (2017) Preliminary global paleogeographic maps through the Greenhouse-Icehouse transition: forcing of the Drake Passage and Asian Monsoons. EGU General Assembly 2017, Geophysical Research Abstracts, Vol. 19.

Qiao, Q., Huang, B., Biggin, A. J., \& Piper, J. D. A. (2017). Late Cenozoic evolution in the Pamir-Tian Shan convergence: New chronological constraints from the magnetostratigraphic record of the southwestern Tianshan foreland basin (Ulugqat area). Tectonophysics, 717, 51-64. https://doi.org/10.1016/j.tecto.2017.07.013

Radionova, E. P., Beniamovski, V. N., Iakovleva, A. I., Muzylov, N. G., Oreshkina, T. V., Shcherbinina, E. A., ... Kozlova, G. E. (2003). Early Paleogene transgressions: Stratigraphical and sedimentological evidence from the northern Peri-Tethys. Special Papers-Geological Society of. America, 369, 239-262. https://doi. org/10.1130/0-8137-2369-8.239

Raffi, I., Backman, J., \& Pälike, H. (2005). Changes in calcareous nannofossil assemblages across thePaleocene/Eocene transition from the paleo-equatorial Pacific Ocean. Palaeogeography, Palaeoclimatology, Palaeoecology, 226, 93-126. https://doi.org/10.1016/j.palaeo.2005.05.006

Ramstein, G., Fluteau, F., Besse, J., \& Joussaume, S. (1997). Effect of orogeny, plate motion and land-sea distribution on Eurasian climate change over the past 30 million years. Nature, https://doi. org/10.1038/386788a0

Replumaz, A., Negredo, A. M., Villaseñor, A., \& Guillot, S. (2010). Indian continental subduction and slab break-off during Tertiary collision. Terra Nova, 22(4), 290-296. https://doi. org/10.1111/j.1365-3121.2010.00945.x

Roe, G. H., Ding, Q., Battisti, D. S., Molnar, P., Clark, M. K., \& Garzione, C. N. (2016). A modeling study of the response of Asian summertime climate to the largest geologic forcings of the past 50 Ma. Journal of Geophysical Research: Atmospheres, 121(10), 5453-5470. https://doi.org/10.1002/2015JD024370

Rutte, D., Ratschbacher, L., Khan, J., Stübner, K., Hacker, B. R., Stearns, M. A., ... Tichomirowa, M. (2017). Building the Pamir-Tibetan
Plateau-Crustal stacking, extensional collapse, and lateral extrusion in the Central Pamir: 2. Timing and Rates. Tectonics, 36, 385-419.

Scott, R. W., Wan, X., Sha, J., \& Wen, S.-X. (2010). Rudists of Tibet and the tarim basin, China: Significance to requieniidae phylogeny. Journal of Paleontology, 84(3), 444-465. https://doi. org/10.1666/09-137.1

Şengör, A. M. C., Altıner, D., Cin, A., Ustaömer, T., \& Hsü, K. J. (1988). Origin and assembly of the Tethyside orogenic collage at the expense of Gondwana Land. Geological Society, London, Special Publications, 37(1), 119-181. https://doi.org/10.1144/GSL. SP.1988.037.01.09

Şengör, A. M. C., Natal'in, B. A., \& Burtman, V. S. (1993). Evolution of the Altaid tectonic collage and Palaeozoic crustal growth in Eurasia. Nature Letters, 364, 299-307. https://doi.org/10.1038/364299a0

Shcherbinina, E., Gavrilov, Y., Iakovleva, A., Pokrovsky, B., Golovanova, O., Aleksandrova, G., et al. (2016). Environmental dynamics during the Paleocene-Eocene thermal maximum (PETM) in the northeastern Proto-Paratethys revealed by high-resolution micropalaeontological and geochemical studies of a Caucasian key section. Palaeogeography, Palaeoclimatology, Palaeoecology, 456, 60-81.

Sheldon, E. (2002). Paleogene nannofossil biostratigraphy of the Kangâmiut-1 and Nukik-2 wells, offshore West Greenland. Marine and Petroleum Geology, 20, 1031-1041. https://doi.org/10.1016/ S0264-8172(02)00119-8

Sobel, E. R. (1995). Basin analysis and apatite fission-track thermochronology of the Jurassic-Paleogene southwest Tarim Basin, NW China [Phd dissertation] (p. 308). Stanford, CA: Stanford University.

Sobel, E. R., Chen, J., \& Heermance, R. V. (2006). Late OligoceneEarly Miocene initiation of shortening in the Southwestern Chinese Tian Shan: Implications for Neogene shortening rate variations. Earth and Planetary Science Letters, 247(1-2), 70-81. https://doi. org/10.1016/j.eps1.2006.03.048

Sobel, E. R., \& Dumitru, T. A. (1997). Thrusting and exhumation around the margins of the western Tarim basin during the India-Asia collision. Journal of Geophysical Research: Solid Earth, 102(B3), 5043-5063. https://doi.org/10.1029/96JB03267

Song, B., Zhang, K., Lu, J., Wang, C., Xu, Y., \& Greenough, J. (2013). The middle Eocene to early Miocene integrated sedimentary record in the Qaidam Basin and its implications for paleoclimate and early Tibetan Plateau uplift. Canadian Journal of Earth Sciences, 50(2), 183-196. https://doi.org/10.1139/cjes-2012-0048

Speijer, R. P. (1994). Extinction and recovery patterns in benthic foraminiferal paleocommunities across the Cretaceous/Paleogene and Paleocene/Eocene boundaries. Geologica Ultraiectina, 124, 191. [Faculteit Aardwetenschappen, Universiteit Utrecht].

Sun, J., \& Jiang, M. (2013). Eocene seawater retreat from the southwest Tarim Basin and implications for early Cenozoic tectonic evolution in the Pamir Plateau. Tectonophysics, 588, 27-38. https://doi. org/10.1016/j.tecto.2012.11.031.

Sun, J., Li, Y., Zhang, Z., \& Fu, B. (2009). Magnetostratigraphic data on Neogene growth folding in the foreland basin of the southern Tianshan Mountains. Geology, 37(11), 1051-1054. https://doi. org/10.1130/G30278A.1

Sun, J., Windley, B. F., Zhang, Z., Fu, B., \& Li, S. (2016). Diachronous seawater retreat from the southwestern margin of the Tarim Basin in the late Eocene. Journal of Asian Earth Sciences, 116, 222-231. https://doi.org/10.1016/j.jseaes.2015.11.020

Tang, T., Yang, H., Lan, X., Yu, C., Xue, Y., Zhang, Y., ... Wei, J.. (1989). Marine Late Cretaceous and Early tertiary stratigraphy 
and Petroleum Geology in Western Tarim Basin, China (118 pp). Beijing: Science Press (In Chinese with English abstract).

Tang, W., Zhong, X., Guo, C., Yan, Z., \& Ye, L. (1992). Abnormal event of carbon stable isotope at the boundary between Cretaceous and Tertiary in Altax section in Xinjiang Autonomous region. Acta Petrolei Sinica, 13(2), 209-214.

van Hinsbergen, D. J. J., Lippert, P. C., Dupont-Nivet, G., McQuarrie, N., Doubrovine, P. V., Spakman, W., \& Torsvik, T. H. (2012). Greater India Basin hypothesis and a two-stage Cenozoic collision between India and Asia. Proceedings of the National Academy of Sciences, 109(20), 7659-7664. https://doi.org/10.1073/ pnas.1117262109

van Hinsbergen, D. J. J., Lippert, P. C., Li, S., Huang, W., Advokaat, E. L., \& Spakman, W. (2018). Reconstructing Greater India: Paleogeographic, kinematic and geodynamic perspectives. Tectonophysics. (in press), https://doi.org/10.1016/j.tecto.2018.04.006

Van Morkhoven, F. P. C. M., Berggren, W. A., \& Edwards, A. S. (1986). Cenozoic cosmopolitan deep-water benthic foraminifera. Bulletin Des Centres De Recherches Exploration-Production Elf-Aquitaine. Mémoire, 11, 421.

Wan, X., Jiang, T., Zhang, Y., Xi, D., \& Li, G. (2014). Paleogene marine stratigraphy in China. Lethaia, 47(3), 297-308. https://doi. org/10.1111/let.12071.

Wang, C., Hong, H., Li, Z., Yin, K., Xie, J., Liang, G., ... Zhang, K. (2013). The Eocene-Oligocene climate transition in the Tarim Basin, Northwest China: Evidence from clay mineralogy. Applied Clay Science, 74, 10-19. https://doi.org/10.1016/j. clay.2012.09.003

Wang, D.-N., Sun, X.-Y., \& Zhao, Y.-N. (1990). Late cretaceous to tertiary palynofloras in xinjiang and Qinghai. China. Review of Palaeobotany and Palynology, 65(1-4), 95-104. https://doi. org/10.1016/0034-6667(90)90060-V

Wang, Q., Wyman, D. A., Xu, J., Dong, Y., Vasconcelos, P. M., Pearson, N., ... Chu, Z. (2008). Eocene melting of subducting continental crust and early uplifting of central Tibet: Evidence from centralwestern Qiangtang high-K calc-alkaline andesites, dacites and rhyolites. Earth and Planetary Science Letters, 272(1-2), 158-171. https://doi.org/10.1016/j.epsl.2008.04.034

Wang, W., Zheng, W., Zhang, P., Li, Q., Kirby, E., Yuan, D., ... Pang, J. (2017). Expansion of the Tibetan Plateau during the Neogene. Nature Communications, 8, 1-12. https://doi.org/10.1038/ncomms15887

Warren, J. K. (2010). Evaporites through time: Tectonic, climatic and eustatic controls in marine and nonmarine deposits. EarthScience Reviews, 98(3-4), 217-268. https://doi.org/10.1016/j. earscirev.2009.11.004

Xi, D., Cao, W., Cheng, Y., Jiang, T., Jia, J., Li, Y., \& Wan, X. (2016). Late Cretaceous biostratigraphy and sea-level change in the southwest Tarim Basin. Palaeogeography, Palaeoclimatology, Palaeoecology, 441, 516-527. https://doi.org/10.1016/j.palaeo.2015.09.045

Yang, H. Q., Shen, J. W., Yang, H. J., Zhang, L. J., Li, M., \& Wang, J. P. (2014). Mixed carbonate-clastic facies in the Eocene Kalatar Formation of the southwest Tarim Basin (NW China): Tectonic and climatic controls. Facies, 60(1), 111-131. https://doi.org/10.1007/ s10347-013-0373-1

Yang, W., Dupont-Nivet, G., Jolivet, M., Guo, Z., Bougeois, L., Bosboom, R., ... Heilbronn, G. (2015). Magnetostratigraphic record of the early evolution of the southwestern Tian Shan foreland basin (Ulugqat area), interactions with Pamir indentation and India-Asia collision. Tectonophysics, 644, 122-137. https://doi.org/10.1016/j. tecto.2015.01.003

Ye, D., Tang, W., Wei, J., Xu, D., \& Mao, X. (1992). Geochemical markers of the Cretaceous-Tertiary boundary event in the Altax section. Tarim Basin, Acta Petrolei Sinica, 13(2), 202-208.

Ye, C., Yang, Y., Fang, X., \& Zhang, W. (2016). Late Eocene clay boron-derived paleosalinity in the Qaidam Basin and its implications for regional tectonics and climate. Sedimentary Geology, 346, 49-59. https://doi.org/10.1016/j.sedgeo.2016.10.006

Yin, A., Craig, P., \& Harrison, T. M. (1998). Late Cenozoic tectonic evolution of the southern Chinese Tian Shan. Tectonics, 17(1), 1-27. https://doi.org/10.1029/97TC03140

Yin, A., \& Harrison, T. M. (2000). E Volution of the H Ealth C Are. Annual Reviews of Earth and Planetary Sciences, 28, 211-280. https://doi.org/10.1080/01947641003598252

Yin, A., Rumelhart, P. E., Butler, R., Cowgill, E., Harrison, T. M., Foster, D. A., ... Raza, A. (2002). Tectonic history of the Altyn Tagh fault system in northern Tibet inferred from Cenozoic sedimentation. Bulletin of the Geological Society of America, 114(10), 1257-1295. https://doi.org/10.1130/0016-7606(2002) 114<1257:THOTAT>2.0.CO;2

Young, J. R., Bown, P. R., \& Lees, J. A. (eds). Nannotax3 website. International Nannoplankton Association. http://ina.tmsoc.org/Nannotax3

Young, J. R., Wade, B. S., \& Huber, B. T. (Eds.) pforams@mikrotax website. (2018). http://ww.mikrotax.org/pforams

Zhang, S., Hu, X., Han, Z., Li, J., \& Garzanti, E. (2018). Climatic and tectonic controls on Cretaceous Paleogene sea-level changes recorded in the Tarim epicontinental sea. Palaeogeography, Palaeoclimatology, Palaeoecology, 501, 92-110. https://doi. org/10.1016/j.palaeo.2018.04.008

Zhang, Z., Flatøy, F., Wang, H., Bethke, I., Bentsen, M., \& Guo, Z. (2012). Early Eocene Asian climate dominated by desert and steppe with limited monsoons. Journal of Asian Earth Sciences, 44, 24-35. https://doi.org/10.1016/j.jseaes.2011.05.013

Zhang, Z., Wang, H., Guo, Z., \& Jiang, D. (2007). What triggers the transition of palaeoenvironmental patterns in China, the Tibetan Plateau uplift or the Paratethys Sea retreat? Palaeogeography, Palaeoclimatology, Palaeoecology, 245, 317-331

Zhang, C. L., Zou, H. B., Li, H. K., \& Wang, H. Y. (2013). Tectonic framework and evolution of the Tarim Block in NW China. Gondwana Research, 23, 1306-1315.

\section{SUPPORTING INFORMATION}

Additional supporting information may be found online in theSupportingInformationsectionattheendofthearticle.

How to cite this article: Kaya MY, Dupont-Nivet G, Proust J-N, et al. Paleogene evolution and demise of the proto-Paratethys Sea in Central Asia (Tarim and Tajik basins): Role of intensified tectonic activity at ca. 41 Ma. Basin Res. 2019;31:461-486. https://doi. org/10.1111/bre. 12330 